Florida International University FIU Digital Commons

8-8-2012

\title{
Essays on the Effect of Tax Exemption on Competitiveness, Performance and Portfolio Risk of Credit Unions and Subchapter S Banks
}

Ajeet Jain

Florida International University, ajeetjain@yahoo.com

DOI: $10.25148 /$ etd.FI12110702

Follow this and additional works at: https://digitalcommons.fiu.edu/etd

\section{Recommended Citation}

Jain, Ajeet, "Essays on the Effect of Tax Exemption on Competitiveness, Performance and Portfolio Risk of Credit Unions and Subchapter S Banks" (2012). FIU Electronic Theses and Dissertations. 718.

https://digitalcommons.fiu.edu/etd/718 


\title{
FLORIDA INTERNATIONAL UNIVERSITY
}

Miami, Florida

ESSAYS ON THE EFFECT OF TAX EXEMPTION ON COMPETITIVENESS, PERFORMANCE AND PORTFOLIO RISK OF CREDIT UNIONS AND

\section{SUBCHAPTER S BANKS}

\author{
A dissertation submitted in partial fulfillment of the \\ requirements for the degree of \\ DOCTOR OF PHILOSOPHY \\ in \\ BUSINESS ADMINISTRATION
}

by

Ajeet Jain 
To: Dean Joyce Elam

College of Business Administration

This dissertation, written by Ajeet Jain, and entitled Essays on the effect of tax exemption on competitiveness, performance and portfolio risk of credit unions and Subchapter S banks, having been approved in respect to style and intellectual content, is referred to you for judgment.

We have read this dissertation and recommend that it be approved.

Wen-Hsiu J. Chou

Gauri Ghai

Edward R. Lawrence

Arun J. Prakash, Major Professor

Date of Defense: August 8, 2012

The dissertation of Ajeet Jain is approved.

Dean Joyce Elam

College of Business Administration

Dean Lakshmi N. Reddi

University Graduate School

Florida International University, 2012 
C Copyright 2012 by Ajeet Jain

All rights reserved. 


\section{ACKNOWLEDGMENTS}

I would like to thank the members of my dissertation committee: Dr. Arun J. Prakash, Dr. Gauri Ghai, Dr. Edward Lawrence and Dr. Wen-Hsiu J.Chou for their continuous encouragement and guidance.

I would like to express my deepest gratitude to my major professor, Dr. Arun J. Prakash, for his mentorship and support throughout my doctoral study. I would also like to thank Dr. Edward Lawrence for his continuous support and guidance. I would also like to thank the finance faculty, staff and fellow doctoral students for their support.

I dedicate this dissertation to my parents, my wife Preti and my daughter Chinni. 


\section{ABSTRACT OF THE DISSERTATION \\ ESSAYS ON THE EFFECT OF TAX EXEMPTION ON COMETITIVENESS, PERFORMANCE AND PORTFOLIO RISK OF CREDIT UNIONS AND SUBCHAPTER S BANKS \\ by}

Ajeet Jain

Florida International University, 2012

Miami, Florida

Professor Arun J. Prakash, Major Professor

The tax exemptions granted to financial institutions like Subchapter S banks and credit unions cost billions of dollars to the government. The dissertation investigates the effect of tax exemption on competitiveness, performance and portfolio risk of credit unions and Subchapter S banks. The methodologies include difference in differences estimation, univariate and multivariate analysis.

The first essay entitled "The tax exemption to Subchapter S banks: who gets the benefit?" investigates the effect of tax exemption to Subchapter S banks on stakeholders and on job creation. Specifically, we investigate the effect of adoption of Subchapter S status on the four stakeholders of the banks: the customers of the bank, the employees of the bank, the owners of the bank and the government. The results indicate that the tax exemptions to Subchapter S banks do not create new jobs, and that the owners of the bank are the sole beneficiary of the tax exemptions since there is a significant increase in bank's return on equity after it adopts the Subchapter S status. 
The second essay entitled "A comparison of credit unions and Subchapter S banks: who shares higher tax benefits with customers?" examines whether credit unions are doing a better job of sharing the tax benefit with its customers. The results indicate that the credit union members do not receive the benefit in terms of lower loan rates, higher deposit rates or lower service charges. The findings also indicate that tax exemptions have been directed to support inefficient operations.

The third essay entitled "Asset quality comparison between credit unions and Subchapter S banks" compares the asset quality of for-profit Subchapter S banks with not-for-profit credit unions. The results indicate that credit unions have better asset quality, but Subchapter S banks are superior in utilizing assets and generating higher net interest margin. 
TABLE OF CONTENTS

CHAPTER $\quad$ PAGE

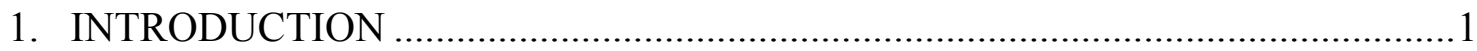

2. ESSAY 1: THE TAX EXEMPTIONS TO SUBCHAPTER S BANKS: WHO GETS

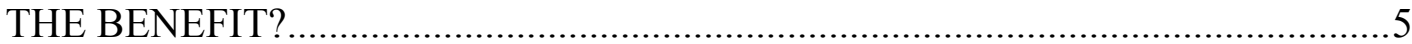

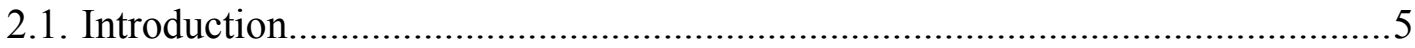

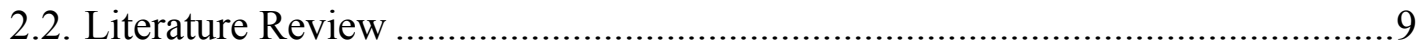

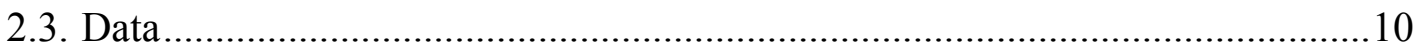

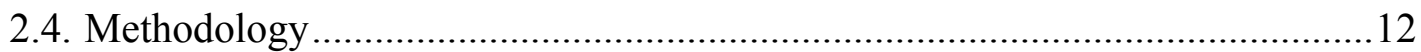

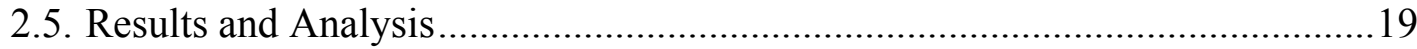

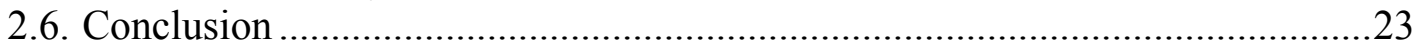

3. ESSAY 2: A COMPARISON OF CREDIT UNIONS AND SUBCHAPTER S BANKS: WHO SHARES HIGHER TAX BENEFIT WITH CUSTOMERS? ........29

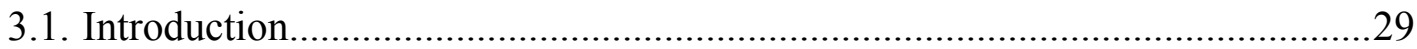

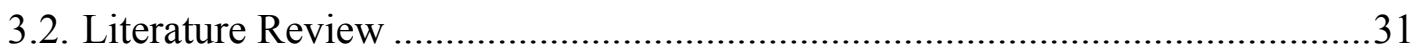

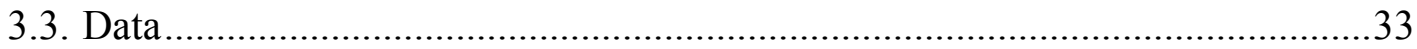

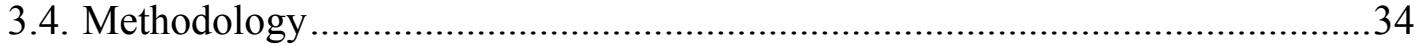

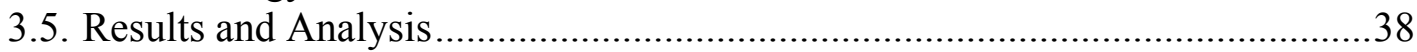

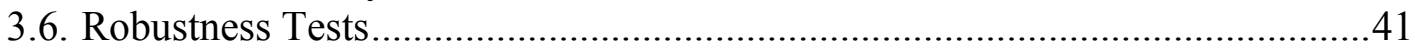

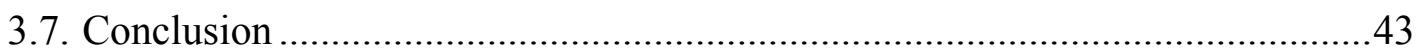

4. ESSAY 3: ASSET QUALITY COMPARISON BETWEEN CREDIT UNIONS AND

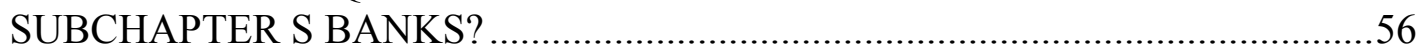

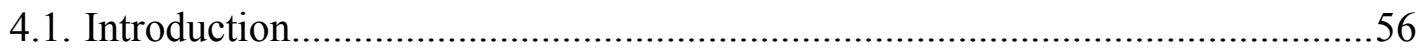

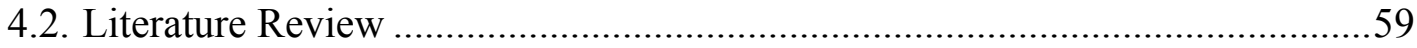

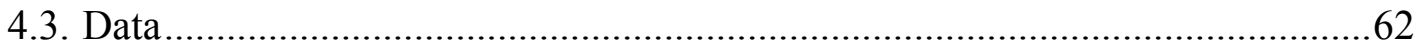

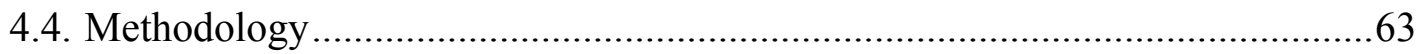

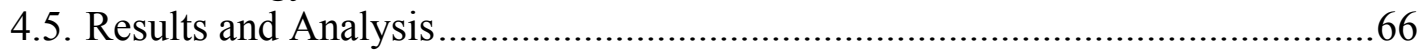

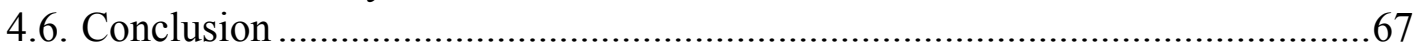

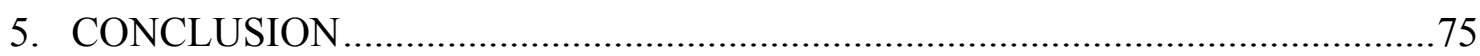

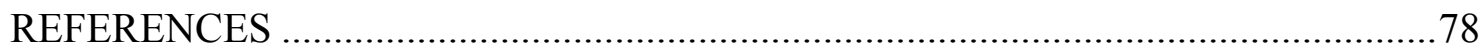

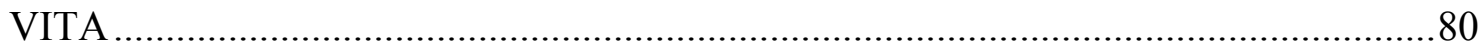




\section{LIST OF TABLES}

TABLE

PAGE

1. Descriptive Statistics for Subchapter S and non-Subchapter S Banks .26

2. Comparison of Subchapter S and non-Subchapter S banks: Univariate Analysis......27

3. The Effect of Subchapter S Status on Stakeholders...............................................28

4. Descriptive Statistics for Credit Unions and Subchapter S Banks ..........................45

5. Comparison of Credit Unions and Subchapter S Banks: Univariate Analysis ...........46

6. Comparison of Credit Unions and Subchapter S Banks for the Period 2005-2010....47

7. Comparison of Credit Unions and Subchapter S Banks: Spread..............................48

8. Comparison of Credit Unions and Subchapter S Banks: Average Loan Rate...........49

9. Comparison of Credit Unions and Subchapter S Banks: Average Deposit Rate........50

10. Comparison of Credit Unions and Subchapter Banks: Service Fee ..........................51

11. Comparison of Credit Unions and Subchapter Banks: Wstexp ..............................52

12. Comparison of Credit Unions and Subchapter Banks: Optexp ..............................53

13. Comparison of Credit Unions and Subchapter Banks: Return on Equity...................54

14. Comparison of Credit Unions and Subchapter Banks: Return on Assets ..................55

15. Asset Quality of Credit Unions and Subchapter S Banks: Univariate Analysis.........69

16. Comparison of Credit Unions and Subchapter Banks: Alll Regression .....................70

17. Comparison of Credit Unions and Subchapter Banks: Nco Regression .....................71

18. Comparison of Credit Unions and Subchapter Banks: Npata Regression..................72

19. Comparison of Credit Unions and Subchapter Banks: Tlta Regression ....................73

20. Comparison of Credit Unions and Subchapter Banks: Nim Regression ................... 74 


\section{CHAPTER 1: INTRODUCTION}

The tax exemption offered to Subchapter S banks and credit unions has resulted in the loss of revenues to the government; therefore it becomes economically important to investigate who is really benefitting from these exemptions. If this benefits the borrowers (depositors) in the form of lower (higher) loan (deposit) rates, creates more jobs, results in better salary and benefits to the employees etc., it definitely has tremendous social value. If, however, this (the tax exemption) results in 'fattening the wallets' of the owners or inefficient operations without any societal benefits as a whole, then these tax exemptions contribute to the so-called "one of the many tax loop-holes." The dissertation investigates the effect of tax exemption on competitiveness, performance and asset quality of credit unions and Subchapter S banks.

In Essay 1, entitled "The tax exemption to Subchapter S banks: who gets the benefit?" we investigate the effect of tax exemption to Subchapter S banks on the stakeholders of the bank and on job creation. We empirically investigate where the tax subsidy to the Subchapter S banks is flowing. We identify four primary stakeholders of a bank: owners, customers, employees and the government (which gives tax relief to these banks). The owners of the bank are benefitted if the return on equity is higher after the adoption of Subchapter S status. The customers are benefitted if the borrowers receive lower loan rates and/or the depositors receive higher deposit rates. The employees of the bank are benefitted if there is an increase in the salaries and benefits for the employees 
after the adoption of Subchapter S status. The government is benefitted if it achieves its objective of generating higher employment opportunities at these banks.

We use difference in differences methodology to measure the effect of adoption of Subchapter S status. We find that the tax exemption has neither benefitted the bank customers in the form of higher deposit rates or lower loan rates nor the employees in the form of increased salaries and/or benefits. Our results show that tax exemption does not lead to any increase in employment opportunities in banks after they adopt the Subchapter S status. In fact, our findings indicate that the shareholders or the owners of the bank are the sole beneficiary of tax benefits since the bank's return on equity increases significantly after it adopts the Subchapter S status. Furthermore, we also find that the growth of assets for Subchapter S banks is not significantly different from nonSubchapter S banks.

In Essay 2, entitled "A comparison of credit unions and Subchapter S banks: who shares higher tax benefits with customers?" we investigate if federally chartered credit unions are doing a better job of sharing the tax benefit with their customers. The credit unions are also exempted from federal taxation at corporate level just like Subchapter S banks. However, there is a key difference between the two regarding taxation of retained earnings. Unlike Subchapter S banks, credit unions do not pay taxes on retained earnings. The credit unions have defended its special tax exemption of retained earnings on the pretext of their not-for-profit nature and claims that credit unions have a special purpose of serving individuals of limited means. We compare credit unions and Subchapter S banks to investigate which of the two financial institutions shares higher tax benefit with customers by comparing the loan rates, deposit rates and fee charges. We also compare 
the return on equity, return on assets, wage-salary-travel expenses and operating expenses to investigate if the tax exemptions have been used to support inefficient operations. We find that the tax exemption to credit unions has not resulted in benefits to its borrowers (depositors) in the form of lower (higher) loan (deposit) rates. We find that the credit union members pay higher service charges and fees compared to the customers of the Subchapter S banks. We also find that credit unions have higher operating expenses compared to Subchapter S banks. Credit unions have lower return on equity as well as lower return on assets compared to Subchapter S banks, indicating inefficient operations.

In Essay 3, entitled "Asset quality comparison between credit unions and Subchapter S banks" we compare the asset quality of financial institutions that have similar tax exemptions but different ownership structure and objectives. The asset quality of financial institutions has gained increased focus in the wake of the financial crisis of 2008-2009. The objective of for-profit Subchapter S banks is to maximize the wealth of the shareholders, whereas the objective of not-for-profit credit unions is to serve the people of the community who have limited means and limited access to finances. The objective of the financial institution can influence its asset portfolio. Subchapter S banks can make risky loans in order to maximize shareholder's wealth, whereas credit unions can add risk to their asset portfolio by serving customers of limited means. We compare three different measures of asset quality for the credit unions and Subchapter S banks. These asset quality measures are allowance for loan losses as a percentage of total loans, net charge offs as a percentage of average assets, and nonperforming assets as a percentage of total assets. Since net interest margin has a negative relationship with asset quality, we compare it for credit unions and Subchapter S banks as an indirect measure 
for asset quality. We find that the Subchapter S banks have higher allowance of loans and lease losses and higher non-performing assets. There is no significant difference in net charge-off at the two institutions. We also find that net interest margin is higher at Subchapter S banks. Overall, we find that that the asset quality is better at credit unions.

The findings of the dissertation can have significant policy implications about the ongoing debate if tax exemptions to Subchapter S banks and credit unions are justified or create any value particularly in times of record budget deficits. This study extends the existing literature on financial institutions by investigating the effect of tax exemption on job creation, competitiveness, performance and asset quality of credit unions and Subchapter S banks. 


\section{CHAPTER 2: ESSAY 1}

\section{THE TAX EXEMPTIONS TO SUBCHAPTER S BANKS: WHO GETS THE}

\section{BENEFIT?}

\subsection{Introduction}

The Small Business Job Protection Act of 1996 allows banks to convert to Scorporations and avoid double taxation. The corporation is treated as a partnership for tax purposes and the shareholders pay federal income taxes on pass through earnings, and thus avoid taxes at the corporate level ${ }^{1}$. Since 1997, a large number of banks in the U.S. have elected Subchapter S tax treatment to reap the benefits of tax exemption. The number has increased steadily from 606 in 1997 to over 2300 banks in 2010, (see Figure 1) resulting in major loss of tax revenues to the government. In June 2011, in a letter to the Senate's banking committee, Dan Berger, the executive vice president of government affairs at the National Association of Federal Credit Unions (NAFCU), states that the tax break to Subchapter S banks is worth more than $\$ 2$ billion $^{2}$. Since the tax exemption to Subchapter S banks has resulted in the loss of revenues to the government, it becomes economically important to investigate who is really benefitting from this exemption. If this results in creation of more jobs, better salary and benefits to the employees etc., it definitely have tremendous social value. If, however, this (the tax exemption) results in

\footnotetext{
1 The favorable tax treatment should allure all banks to adopt the Subchapter S status but there is certain criterion that has to be met in order to qualify as Subchapter S institution. The restrictions include limits to one class of stock and on the type and the number of shareholders. The Subchapter S bank can have no more than 100 shareholders and its only shareholders are individuals, estates, exempt organizations described in section 401(a) or 501(c)(3) or certain trusts described in section 1361(c)(2)(A).

${ }^{2}$ http://www.nafcu.org/Tertiary.aspx?id=23056
} 
'fattening the wallets' of the owners without any societal benefits as a whole, then this act will also contribute to the so called one of the many tax loop-holes.

The tax exemption to Subchapter-S banks at the corporate level clearly offers a competitive advantage over $\mathrm{C}$ corporation banks, as Subchapter $\mathrm{S}$ banks can afford to offer higher deposit rates and lower loan rates to its customers and a lower spread would make Subchapter S banks more competitive. As a result of tax exemptions, Subchapter S banks have more cash at hand that can be used to offer better services to customers like multichannel access, internet banking etc., which will result in higher operating expenses. The tax advantage can also be utilized to hire and expand the competitive workforce. Also, the money saved as a result of tax exemption, could fuel bank's growth. In this study we investigate where the tax subsidy is flowing and establish if tax exemptions for the Subchapter $\mathrm{S}$ banks are socially beneficial. We also investigate if the tax exemption to Subchapter S banks leads to any increase in the number of people employed by the bank. The findings of our paper also contribute to the ongoing debate, if tax exemption to businesses leads to job creation.

We use the Ashenfelter and Card's (1985) difference in differences (DID) methodology to measure the changes in the bank due to its adoption of Subchapter S status $^{3 .}$ The difference in differences methodology helps us investigate if there is a difference in the variables of interest as a result of adoption of Subchapter S status by banks in the transition group by comparing it with banks in the control group. Our treatment group consists of banks that have adopted Subchapter S status whereas the

\footnotetext{
${ }^{3}$ This makes sure that the measured changes are due to adoption to Subchapter S and not due to economic and other market factors.
} 
control group consists of banks that have not adopted this (Subchapter S) status. The control group is perfectly matched with the treatment group based on bank's location and size.

We investigate the effect of adoption of Subchapter $S$ status on the four stakeholders of the banks - the customers, employees, owners and the government. The customers comprises of both, the borrowers as well as the depositors. In this study we investigate the following:

- First we investigate whether the tax subsidy is passed on to the borrowers (depositors) in the form of lower (higher) loan (deposit) rates. We find that bank customers, both the depositors as well as the borrowers, do not receive any benefit as a result of adoption of Subchapter S status.

- Second, we investigate if the tax subsidy has resulted in an increase in salaries and benefits for the Subchapter S bank employees or better services to the customers. Note that salaries and benefits are explicitly observable variables whereas the benefit to customers can be gauzed by using the operating expenses as a proxy. An increase (decrease or same) in operating expenses will signal a better (worse or same) service to the customer. That is, if the operating expenses excluding the wage/salary expenses are higher after the conversion, it would signal in a proliferation in better operating environment and facilities for the employees and the customers. We find that the tax subsidy has not resulted in any increase in wages or in operating expenses. 
- Third, we investigate the effect of tax exemption on the owners or the shareholders of the bank. The owners are benefitted if the conversion to Subchapter S results in higher growth in assets or higher return on equity. We find that the tax subsidy does not influence the growth in bank's assets. However, the return on equity increases significantly after the bank adopts the Subchapter S status, indicating that the tax benefit is passed on to the owners of the Subchapter S banks in the form of higher return on equity.

- Finally, we investigate the effect of bank's adoption of Subchapter S status on the fourth stakeholder-the government which provides the tax benefit and considers that tax cuts would create jobs thus improving the economy. We investigate if conversion to Subchapter S status leads to an increase in the number of employees. Our results show that the change in the number of employees for the Subchapter S banks is statistically not different from the change in the number of employees for the non-Subchapter $\mathrm{S}$ banks.

Overall, we find that that tax exemption to Subchapter S Banks has benefitted only the owners of the bank. The tax exemption to Subchapter S banks neither creates any value for any of the stakeholders except possibly for the owners nor creates any employment.

The remainder of the paper is organized as follows. In section 2, we provide the relevant literature and discuss the research questions. In section 3, we present the details 
about the sample construction and variables of interest. In section 4, we present the methodology. In section 5, we present the results. In section 6, we present the conclusion.

\subsection{Literature Review}

To the best of our knowledge, the prior investigations on Subchapter S banks have mainly focused on why and which banks adopt Subchapter S status. In other words, specifically their focus has been mainly to identify the factors that influence the bank's decision to adopt Subchapter S status. Limited work has been done to evaluate the effect of tax exemptions on the stakeholders of the financial institutions that adopt the Subchapter S status.

Hodder, McAnally and Weaver (2003) investigate the motivation behind the conversion to Subchapter S status and find that the banks elect Subchapter S status to avoid double taxation of dividends as well as to avoid alternative minimum taxes. They use logistic regression to show that banks are less likely to convert when conversion restricts access to equity capital and nullifies corporate tax loss carry forwards.

Cyree, Hein and Koch (2005) investigate the other reasons beyond tax avoidance and also examine the factors that affect the choice of Subchapter S status. They specifically compare the characteristics of the bank that adopt Subchapter S status with the banks that do not adopt this status and find that banks that adopt Subchapter S status have higher dividend payout rates, higher profit growth, lower capital, and rely more on core deposits.

Depken, Hollans, and Swidler (2010) investigate if Subchapter S banks have shared the portion of the tax benefit with customers in the form of lower loan rates or 
higher deposit rates as compared to $\mathrm{C}$ banks. They compare the rates for individual products for the Subchapter $\mathrm{S}$ banks and $\mathrm{C}$ banks by using the second quarter data for the year 2008 and find that Subchapter-S deposit (loan) rates are equal to or lower (higher) than similar $\mathrm{C}$ corporation bank rates.

None of the papers so far have investigated the effect of bank's adoption of Subchapter S status on all of its stakeholders. In this essay we evaluate the effect of Subchapter S status not only on the customers of the bank but also on the employees and owners of the bank. We also investigate if tax break to the banks lead to any increase in employment opportunities at these banks.

\subsection{Data}

We collect the data on banks from Highline Financial database for the period 1997 to 2009. To ensure homogeneity in characteristics of the transition group and the control group, our entire sample consists of banks that adopt the Subchapter S status by the end of year 2009. The banks in the transition group are the banks which are nonSubchapter $\mathrm{S}$ in the year (t-1), converts to Subchapter in year (t) and maintains its Subchapter S status in year $(\mathrm{t}+1)$ (See timeline below). On the other hand, the banks in the control group are the banks which are non -Subchapter S in the year (t-1) do not adopt Subchapter $\mathrm{S}$ status in year $(\mathrm{t})$ and continues to be a non- Subchapter $\mathrm{S}$ bank in year $(t+1)$. However, the banks in the control group may change to Subchapter S after year $(\mathrm{t}+1)$. The banks in the control group are matched with banks in the transition group based on state and county codes as well as the size to ensure that the banks in the two groups are located in the same area and are of the similar size. Our final sample of 
transition and control group comprises of 249 banks. The number of banks in each group is reduced primarily because of two reasons. First, the number of banks in the control group is limited and decreases over time. Second, we eliminate all the banks in the transition group for which we don't get a perfect match based on size, state and county codes.

We collect all the relevant data from the following sources;

1. Per capita income (Pcir) by county from the website of the US Department of Commerce, Bureau of Economic Analysis

2. Unemployment rate (Urd) from the website of US Department of Labor, Bureau of Labor Statistics.

3. The data on Metropolitan statistical area (MSA) from the website of US Census Bureau.

The following is the description of variables we use in this study:

- $\quad$ Size $=\log$ of total assets

- Average loan rate $(\mathrm{Alr})=$ interest and fee income on loans/total loans and leases

- Average deposit rate (Adr) $=$ total interest expense/total deposits

- Spread $=$ average loan rate-average deposit rate

- Equityr = total equity/total assets

- Optexpense $=$ operating expenses/total expenses

- Wstexp(wage salary and travel expenses) $=$ non-interest expense (salary and

- Optexsal $=$ optexpense- wstexp employee benefits)/total expenses 
- $\mathrm{Urd}=$ the unemployment rate of the county in which the bank is located

- $\quad$ Pcir $=$ the per capita income of the county in which bank is located

- Mcode (dummy variable) $=1$ if county is in metropolitan statistical area, 0 , otherwise

- Scode (dummy variable) $=1$ if bank is Subchapter S, 0 otherwise.

- Reloan $=$ total amount of real estate loans/total assets

- Delinqr $=$ total amount of delinquent loans and leases/total amount of loans and leases

\subsection{Methodology}

Depending on the appropriateness and purpose at hand, we employ difference in differences (DID) estimation, univariate analysis and multiple regression methodologies to investigate our assertions.

Difference in Differences (DID) Estimation:

Difference in differences (DID) is a commonly used empirical estimation technique to measure the effect of a treatment or impact of a change. The difference in differences methodology helps in investigating the differences between the pre-post period for the treatment and control groups. Gruber and Poterba (1994) used the difference in differences methodology to analyze the impact of the change in the tax law that was expected to increase the purchase of health insurance by self-employed individuals than other employed individuals. Anderson and Meyer (2000) used DID approach to examine the effect of changes in unemployment insurance payroll on a number of outcomes in state of Washington by treating Washington state as treatment group and all other states representing the control groups. 
We employ difference in differences methodology to observe the outcomes for two groups in two time periods as shown in the following time-line figure below.

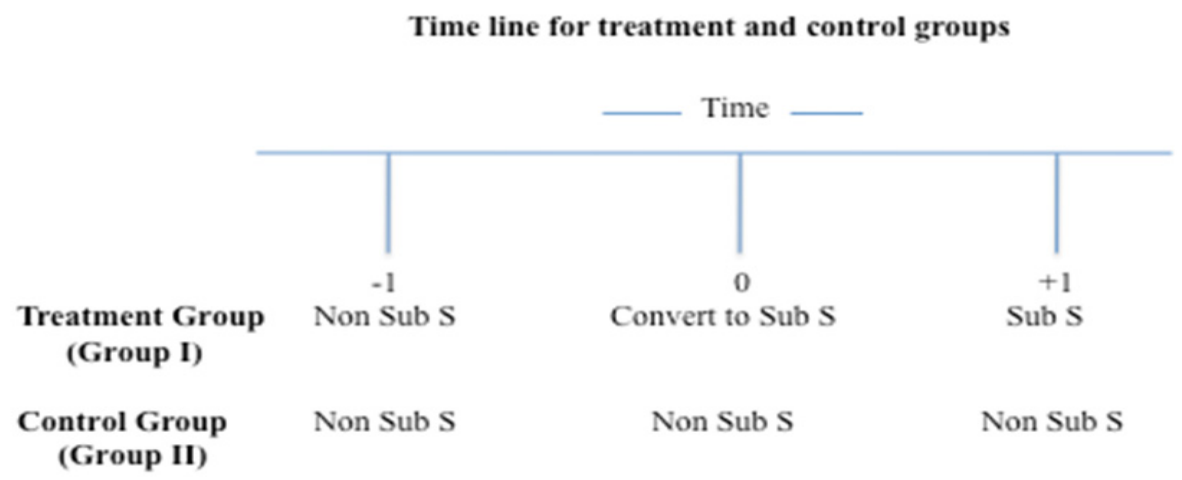

Group I (treatment group) is exposed to a treatment or adoption of Subchapter S status in the second period but not in the first period. In other words, Group I consists of banks that are non-Subchapter $S$ in year $(-1)$, convert to Subchapter $S$ in year $(0)$ and are Subchapter S in year $(+1)$. Group II (Control Group) is not exposed to the treatment during either period. In other words, Group II consists of banks that are non-Subchapter S in all the period under investigation, that is, they remain non-Subchapter $\mathrm{S}$ banks in corresponding years $-1,0$ and +1 . We use the dummy variable Scode and assign it a value of 1 for the banks in Group I and 0, otherwise. To obtain the corresponding control groups for the sample of banks experiencing charter conversion, we match with banks of similar characteristics that experienced no change of charter in the respective year. The banks in Group I and Group II are perfectly matched based on State and County codes and the size. We compute the change in the variables of interest from first period to second period for both the groups. We investigate if these changes in the variables of interest are significantly different for the two groups. The difference in differences 
methodology removes biases from comparisons over time in the treatment group that could be the result of trends and it helps us control for macroeconomic factors like changes in interest rates, state of economy etc.

We compute the change in different variables for the two groups between Year (-1) and Year $(+1)$. The list of variables used in the analysis is as follows:

- $\Delta$ Size $=$ change in the size of the bank from year $(-1)$ to year $(+1)$

- $\Delta$ Equityr $=$ change in the equity ratio of the bank from year $(-1)$ to year $(+1)$

- $\Delta \mathrm{Urd}=$ change in the unemployment rate of the county in which the bank is located from year $(-1)$ to year $(+1)$

- $\Delta$ Pcir $=$ change in the per capita income of the county in which the bank is located from year $(-1)$ to year $(+1)$

- $\Delta$ Delinqr $=$ change in the proportion of delinquent loans of the bank from year $(-1)$ to year $(+1)$

- $\Delta$ Spread $=$ change in the spread of the bank from year $(-1)$ to year $(+1)$

- $\Delta \mathrm{Alr}=$ change in the average loan rate of the bank from year (-1) to year $(+1)$

- $\Delta$ Reloan $=$ change in the proportion of real estate loans of the bank from year $(-1)$ to year $(+1)$

- $\Delta \mathrm{Adr}=$ change in the average deposit rate of the bank from year (-1) to year $(+1)$

- $\Delta$ Growth $=$ change in the growth of assets of the bank from year (-1) to year $(+1)$

- $\Delta$ Optexsal $=$ change in the operating expenses excluding wage and salary expenses for the bank from year $(-1)$ to year $(+1)$

- $\Delta \mathrm{Emp}=$ change in the number of employees of the bank from year (-1) to year $(+1)$ 
- $\Delta \mathrm{W}$ stexp $=$ change in the wage, salary and travel expenses for the bank from year $(-1)$ to year $(+1)$

- $\Delta \mathrm{Roe}=$ change in the return on equity of the bank from year $(-1)$ to year $(+1)$

Univariate Analysis:

Our goal is to test if the ratios for the Subchapter S bank structure $\left(\mu_{1}\right)$ are different from the ratios of the non-Subchapter $\mathrm{S}$ structure $\left(\mu_{2}\right)$. Hence we test the following null-hypothesis:

$$
H_{0}: \mu_{1}-\mu_{2}=0
$$

Against the alternative hypothesis:

$$
H_{1}: \mu_{1}-\mu_{2} \neq 0
$$

We first determine whether the population variances are statistically equal using the Snedecor's F-test. If we find that the population variances are statistically same then we use the standard two-independent sample t-test to test the null hypothesis posited above. ${ }^{4}$ If, however, we find that the population variances are statistically unequal, we use the two independent sample t-test for equality of population means proposed by Satterthwaite (1946). If the null hypothesis is true, the t-statistic will have Student's tdistribution with Welch's (1947) "modified" degrees of freedom given by;

\footnotetext{
${ }^{4}$ For the test statistics and procedures to test the equality of two population variances and the equality of two population means when population variances are unknown but equal see any basic standard statistics textbook.
} 


$$
d f=\frac{\left(\frac{s_{1}^{2}}{n_{1}}+\frac{s_{2}^{2}}{n_{2}}\right)^{2}}{\frac{\left(s_{1}^{2} / n_{1}\right)^{2}}{n_{1}}+\frac{\left(s_{2}^{2} / n_{2}\right)^{2}}{n_{2}}}
$$

where $n_{i}$ and $s_{i}^{2}(\mathrm{i}=1,2)$ respectively are the sample size and the sample variance of the $i^{\text {th }}$ sample.

\section{Regression Analysis:}

Similar to Mayne (1977) and Thomson (1991), in our regression analysis we provide control of the local economy in which the banks compete, namely, the county unemployment rate, the per-capita income of the county, and whether or not the bank is in a metropolitan area. We control for the size of the bank because economies of scale are experienced by banks as they grow larger which will affect the spread and other variables included in the study ${ }^{5}$. We control for delinquency ratio as it is an indicator of the quality of bank's loan portfolio and will affect the spread and average loan rates for the bank. We also control for the amount of real estate loan as variation in product mix can affect average loan and average deposit rates.

To investigate if the Subchapter $\mathrm{S}$ bank is passing on the tax benefits to its customers, we estimate the parameters of the regression equation given in equation (2.1). Here, we regress change in spread $(\Delta$ Spread) as the dependent variable over a dummy variable Scode which takes a value 1 for Subchapter S bank (Group I) and a value 0 for non-Subchapter S banks (Group II). We investigate the significance of the dummy

\footnotetext{
${ }^{5}$ Hughes et al (2001) find that large banks face significant scale economies that increase with bank size.
} 
variable Scode. A negative and significant coefficient on Scode will indicate that spread reduces more for the Subchapter S banks than for the banks in the control group. Essentially we estimate the parameters of the regression equation.

$$
\begin{gathered}
\Delta \text { Spread }=\alpha+\beta_{1} \Delta \text { Size }+\beta_{2} \Delta \text { Re loan }+\beta_{3} \Delta \text { Equityr }+\beta_{4} \Delta \text { Urd }+ \\
\beta_{5} \Delta \text { Pcir }+\beta_{6} \text { Scode }+\beta_{7} \text { Mcode }+\beta_{8} \Delta \text { Delinqr }+\varepsilon
\end{gathered}
$$

A change in the spread as a result of Subchapter $\mathrm{S}$ conversion does not specifically tell us if change to Subchapter S status has affected loan or deposit rates. In order to find this we regress change in average loan rate $(\Delta$ Alr $)$ and change in average deposit rate ( $\triangle \mathrm{Adr})$ as the dependent variable to analyze if there is a significant difference between the change in the average loan rate and the change in average deposit rate for the two groups. A lower loan rate and a higher deposit rate will make the Subchapter S bank more competitive. We use the following equations (2.2) and (2.3) to compare the changes in the average loan and average deposit rates for the two groups.

$$
\begin{gathered}
\Delta \text { Alr }=\alpha+\beta_{1} \Delta \text { Size }+\beta_{2} \Delta \text { Re loan }+\beta_{3} \Delta \text { Equityr }+\beta_{4} \Delta U r d+\beta_{5} \Delta \text { Pcir }+ \\
\beta_{6} \text { Scode }+\beta_{7} \text { Mcode }+\beta_{8} \Delta \text { Delinqr }+\varepsilon \\
\Delta A d r=\alpha+\beta_{1} \Delta \text { Size }+\beta_{2} \Delta \text { Re loan }+\beta_{3} \Delta \text { Equityr }+\beta_{4} \Delta U r d+\beta_{5} \Delta \text { Pcir }+ \\
\beta_{6} \text { Scode }+\beta_{7} \text { Mcode }+\beta_{8} \Delta \text { Delinqr }+\varepsilon
\end{gathered}
$$

The owner of Subchapter S bank may utilize the tax subsidy to make higher reinvestments which may in turn lead to higher growth in assets. We use the regression equation (2.4) to examine if the growth for the Subchapter S banks is higher than the growth in the non-Subchapter S banks. 


$$
\begin{aligned}
\Delta \text { Growth } & =\alpha+\beta_{1} \Delta \text { Size }+\beta_{2} \Delta \operatorname{Re} \text { loan }+\beta_{3} \Delta \text { Equityr }+\beta_{4} \Delta U r d+\beta_{5} \Delta \text { Pcir } \\
& +\beta_{6} \text { Scode }+\beta_{7} \text { Mcode }+\beta_{8} \Delta \text { Delinqr }+\mathcal{E}
\end{aligned}
$$

The owner of Subchapter S bank may utilize the tax benefit to offer higher wage salary and travel benefits (Wstexp) to its employees. Using equation (2.5) we examine if there is a significant increase in the wages, salary and travel expenses for the Subchapter S banks as compared to the non-Subchapter S banks.

$$
\begin{gathered}
\Delta W \text { st exp }=\alpha+\beta_{1} \Delta \text { Size }+\beta_{2} \Delta \operatorname{Reloan}+\beta_{3} \Delta \text { Equityr }+\beta_{4} \Delta U r d+\beta_{5} \Delta P \text { cir }+ \\
\beta_{6} \text { Scode }+\beta_{7} \text { Mcode }+\beta_{8} \Delta \text { Delinqr }+\varepsilon
\end{gathered}
$$

If Subchapter S banks use the tax dollars in improving the work environment of their employees or in providing better facilities and services to their customers then the Subchapter S banks will have higher operating expenses as compared to the nonSubchapter S banks. The Optexsal variable includes expenses related to the use of premises, equipment, furniture, etc., but it does not include the salaries and benefits of employees of the bank. We use the equation (2.6) to examine if there is a significant difference between the changes in the operating expenses ( $\Delta$ Optexsal) for Subchapter $\mathrm{S}$ banks as compared to the non-Subchapter S banks.

$$
\begin{gathered}
\Delta \text { Optexsal }=\alpha+\beta_{1} \Delta \text { Size }+\beta_{2} \Delta \operatorname{Re} \text { loan }+\beta_{3} \Delta \text { Equityr }+\beta_{4} \Delta U r d+\beta_{5} \Delta \text { Pcir }+ \\
\beta_{6} \text { Scode }+\beta_{7} \text { Mcode }+\beta_{8} \Delta \text { Delinqr }+\mathcal{E}
\end{gathered}
$$

There is an ongoing debate that tax benefits to businesses leads to job creation. We investigate if the tax benefits extended to Subchapter S banks have been utilized to 
hire more employees. We use the equation (2.7) to examine if there is a significant difference between the changes in the number of employees $(\Delta \mathrm{Emp})$ for the two groups.

$$
\begin{gathered}
\Delta \text { Emp }=\alpha+\beta_{1} \Delta \text { Size }+\beta_{2} \Delta \operatorname{Re} \text { loan }+\beta_{3} \Delta \text { Equityr }+\beta_{4} \Delta U r d+\beta_{5} \Delta \text { Pcir }+ \\
\beta_{6} \text { Scode }+\beta_{7} \text { Mcode }+\beta_{8} \Delta \text { Delinqr }+\mathcal{E}
\end{gathered}
$$

Finally, we investigate if the tax subsidy to Subchapter $\mathrm{S}$ has benefitted the owners or shareholders of the bank. The shareholders of the Subchapter S banks are benefitted if there is a significant increase in the return on equity as a result of adoption of Subchapter S status. We use the equation (2.8) to examine if there is a significant difference between the changes in the return on equity ( $\Delta$ Roe) for the two groups.

$$
\begin{gathered}
\Delta \text { Roe }=\alpha+\beta_{1} \Delta \text { Size }+\beta_{2} \Delta \operatorname{Re} \text { loan }+\beta_{3} \Delta \text { Equityr }+\beta_{4} \Delta U r d+\beta_{5} \Delta \text { Pcir }+ \\
\beta_{6} \text { Scode }+\beta_{7} \text { Mcode }+\beta_{8} \Delta \text { Delinqr }+\varepsilon
\end{gathered}
$$

\subsection{Results and Analysis}

In Table 1, we present only the relevant descriptive statistics such as means and standard deviations for the two groups used in the analysis. The change in size for the banks in the control group and the change in size for the banks in the treatment group are presented. The change in equity ratio is negative for the control group in contrast to the treatment group where the change in equity ratio is positive, indicating that shareholders increase their reinvestment as the bank converts to Subchapter S. The change in the proportion of real estate loans is positive for the control group and the treatment group, indicating an increase in the proportion of real estate loans. The change in the delinquency ratio is negative for both the groups indicating an improvement in asset quality over time. The change in per capita income rate and the unemployment rate is 
exactly same for the two groups, confirming that the banks in the two groups have been matched based on geographical location.

In Table 2, we present the univariate analysis of the variables of interest. We find that the change in spread for the treatment group is not significantly different from the change in spread of the control group. We also find that the change in the average deposit rate ( $\Delta$ Adr) and the average loan rate ( $\Delta$ Alr) are not statistically different for the two groups. The banks in the treatment group experience a negative growth, but this growth is not significantly different from the growth in assets of the control group. The change in the wage salary expenses ( $\Delta$ Wstexp) and the change in operating expenses ( $\Delta$ Optexsal) for the two groups are not significantly different from each other. There is an ongoing debate that tax exemption to businesses lead to higher employment. This does not seem to hold true for banks. We observe that the change in the number of employees $(\Delta \mathrm{Emp})$ is not significantly different for the treatment group banks and the control group banks. We find that the return on equity ( $\Delta$ Roe $)$ is much higher for the treatment group and the difference is statistically significant.

In Table 3, we present the results of the regression analysis on the variables of interest reported in Table 2. Each of the variables $\Delta$ Spread, $\Delta \mathrm{Alr}, \Delta \mathrm{Adr}, \Delta \mathrm{Growth}, \Delta \mathrm{W}$ stexp, $\Delta$ Optexsal, $\Delta$ Emp are regressed on the set of control variables and the Scode dummy, which takes value of 1 for the sample of Subchapter S banks, and of 0 for matched sample of non-Subchapter S banks. The Scode dummy coefficient indicates differences resulting from adoption of Subchapter S status. The independent variables are used to control for change in size, change in unemployment rate, change in delinquency ratio, 
and change in proportion of real estate loans, change in equity ratio and for metropolitan statistical area.

We find the coefficient on Scode to be statistically insignificant in the change in spread ( $\Delta$ Spread) regression (equation 2.1), indicating that there is no difference in the change in the spread between the treatment group and the control group. Hence the tax exemption to Subchapter S banks does not result in lower spread. The negative and a significant coefficient on $\Delta$ Size show that as the size of the bank increases, the spread reduces. The negative and significant coefficient on $\Delta$ Equityr indicates that the spread reduces with the increase in the investment from the shareholders. The negative and significant coefficient on $\Delta \mathrm{Urd}$ indicates a negative relationship between unemployment and spread. The coefficient on $\Delta$ Delinqr is positive and significant indicating that an increase in riskier loans leads to higher Spread.

We find the coefficient on Scode to be insignificant for the regression equations (2.2) and (2.3). This confirms the univariate results that there is no difference in the change in the average loan and change in the average deposit rates between the treatment and the control groups. These results indicate that the tax benefit is not passed on to the borrowers by Subchapter S banks in the form of lower loan rates or to the depositors in the form of higher deposit rates. Our results confirm the findings of Depken, Hollans, and Swidler (2010), who find no significant difference in the loan and deposit rates of Subchapter S banks compared to non- Subchapter S banks.

The coefficient on Scode is insignificant for change in growth ( $\Delta$ Growth) regression (equation 2.4) which indicates that the growth of the banks which convert to Subchapter $\mathrm{S}$ is not significantly different from the growth of the banks in the control group. The 
result of growth regression offer support to the findings of Cyree, Hein and Koch (2005) that banks that convert to Subchapter S banks have higher dividend payout rates, hence the tax exemption do not result in higher growth for Subchapter S banks.

The results for change in wage, salary and travel expenses regression (equation 2.5) confirms that the employees of the Subchapter S banks do not receive higher salaries and employee benefits as the coefficient on Scode is insignificant. The result suggests that the tax exemptions to Subchapter S banks have not been passed to the employees of the Subchapter S banks in the form of higher salaries and wages.

The results for change in operating expense regression (equation 2.6) indicates that the change in operating expenses for the treatment group is not significantly different from change in operating expenses for the control group as the coefficient on Scode is insignificant. So, the tax exemption to Subchapter S banks has not been used to offer better services to customers or to provide better work environment for the employees.

Surprisingly, the results of the univariate analysis indicate that the increase in the number of employees is higher for the control group as compared to the treatment group, whereas one would expect the other way around, that is an increase in the number of employees for the treatment group be higher because of reduced taxes. However, the coefficient on Scode is statistically insignificant for the change in number of employees $(\Delta \mathrm{Emp})$ regression (equation 2.7) and it suggest that the change in the number of employees for the treatment group is not significantly different from the control group. The regression results suggest that the tax subsidy to Subchapters $\mathrm{S}$ banks has not resulted in higher employment. 
Finally, we regress the change in the return on equity ( $\Delta$ Roe) on the Scode dummy and the set of control variables (equation 2.8). We find that the coefficient on Scode is positive and highly significant at 1 percent level. The regression results confirm that the change in the return on equity for the treatment group is significantly different from the control group. The tax exemption to Subchapter $\mathrm{S}$ banks has resulted in higher return on equity for its shareholders.

Overall, the univariate results in Table 2 and the regression results in Table 3 suggest that the tax benefits to Subchapter S banks do not create any value for the customers or the employees of the bank. The results suggest that the shareholders or the owners of the Subchapter S banks with higher return on equity are the sole beneficiary of tax exemptions. Moreover, we find that tax exemptions to Subchapter $\mathrm{S}$ banks do not create jobs.

\subsection{Conclusion}

In this paper we investigate the effect of bank's adoption to the Subchapter S status on its stakeholders which we identify as, the bank owners, bank's customers, employees of bank and the government (which gives tax relief to these banks). Using a unique dataset that provides detailed information about the year of adoption of Subchapter S status by banks, we use difference-in-differences estimation to investigate the effect of Subchapter S status adoption on stakeholders of the bank.

We compare the changes in the banks that adopt the Subchapter S status with those banks that do not adopt Subchapter S status in the same time period and measure the effect of tax break on the Subchapter S banks. First, we find that the customers i.e. the 
depositors and the borrowers of the Subchapter S banks do not receive the benefit of tax exemption in the form of higher deposit rates or lower loan rates.

Second, the tax exemptions to Subchapter S banks do not lead to higher employment opportunities by these banks. The findings could have significant policy implications about the ongoing debate if tax exemptions to businesses create jobs.

Third, the shareholders or the owners of the bank are the beneficiary of the tax exemptions offered to Subchapter S banks. Therefore, we conclude that tax exemption to Subchapter S banks does not create any difference in their operations and these banks would have functioned and grown similar to the non-Subchapter S banks even without tax subsidy and tax subsidy to Subchapter $\mathrm{S}$ banks do not create jobs. 
Figure 1: Growth of Subchapter S Banks in US

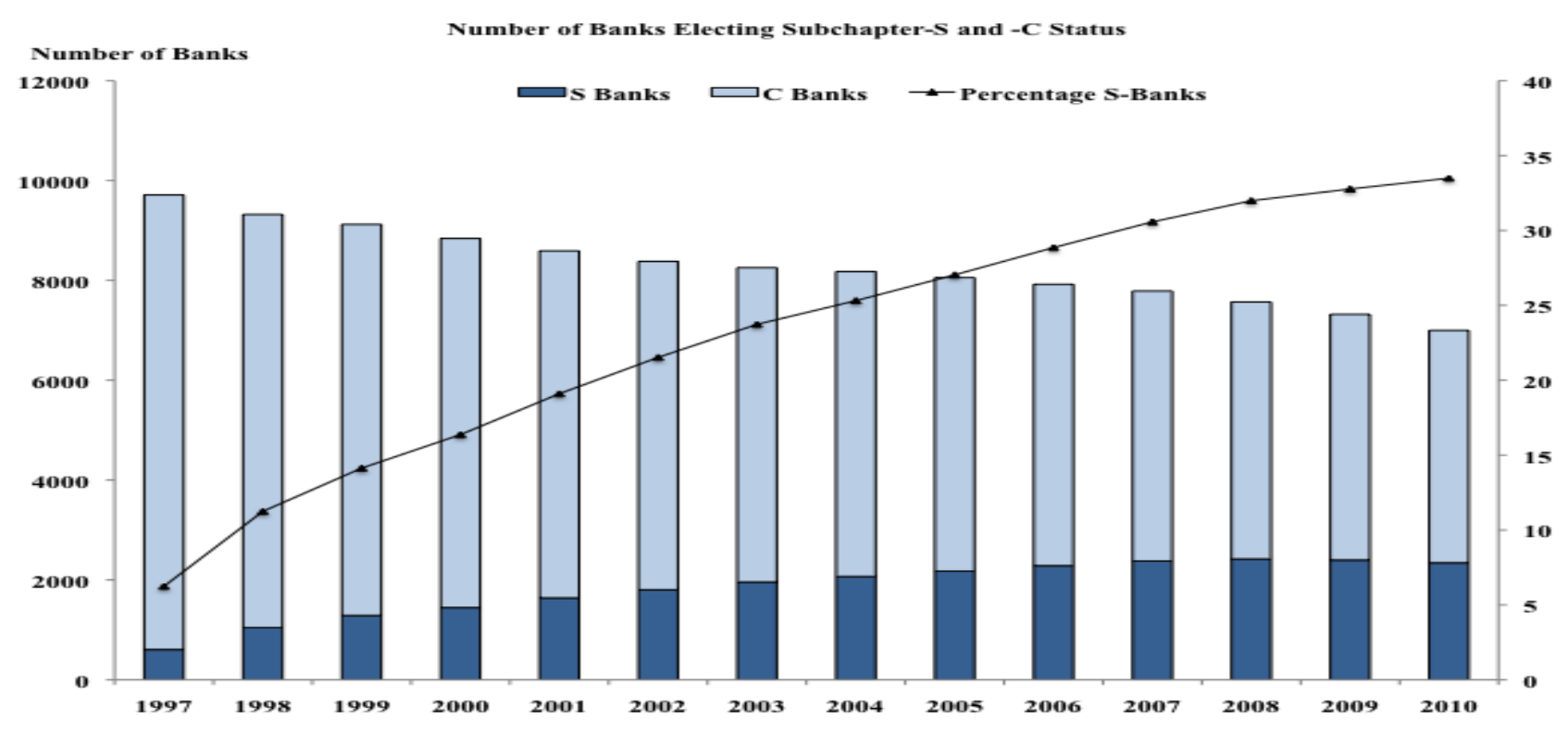

\begin{tabular}{|l|c|c|c|c|c|c|c|c|c|c|c|c|c|c|}
\hline Year & 1997 & 1998 & 1999 & 2000 & 2001 & 2002 & 2003 & 2004 & 2005 & 2006 & 2007 & 2008 & 2009 & 2010 \\
\hline \# of Active Banks & 9711 & 9321 & 9122 & 8840 & 8592 & 8381 & 8255 & 8178 & 8056 & 7922 & 7788 & 7569 & 7321 & 6999 \\
\hline \# of Subchapter S & 606 & 1048 & 1289 & 1447 & 1641 & 1804 & 1959 & 2070 & 2178 & 2286 & 2381 & 2421 & 2399 & 2344 \\
\hline Percentage S Banks & 6.24 & 11.24 & 14.13 & 16.37 & 19.10 & 21.52 & 23.73 & 25.31 & 27.04 & 28.86 & 30.57 & 31.99 & 32.77 & 33.49 \\
\hline
\end{tabular}


Table 1: The relevant descriptive statistics for Subchapter S and non-Subchapter S banks

This table shows the mean and standard deviation of changes in the basic characteristics for Subchapter S and non-Subchapter S banks. All the variables are explained below this table.

\begin{tabular}{lrrrr}
\hline & \multicolumn{2}{c}{$\begin{array}{c}\text { Subchapter S banks } \\
\text { (Treatment Group) }\end{array}$} & \multicolumn{2}{c}{$\begin{array}{c}\text { non-Subchapter S banks } \\
\text { (Control Group) }\end{array}$} \\
\hline Variable & \multicolumn{1}{c}{ Mean } & \multicolumn{1}{c}{ Std Dev } & Mean & Std Dev \\
\hline$\Delta$ Size & 0.0597 & 0.0775 & 0.0678 & 0.0939 \\
$\Delta$ Equityr & 0.0034 & 0.0137 & -0.0001 & 0.0379 \\
$\Delta$ Urd & 0.2944 & 1.1387 & 0.2944 & 1.1387 \\
$\Delta$ Pcir & 1970.3700 & 1406.8000 & 1970.3700 & 1406.8000 \\
$\Delta$ Reloan & 0.0358 & 0.0597 & 0.0269 & 0.0593 \\
$\Delta$ Delinqr & -0.0005 & 0.0045 & -0.0008 & 0.0068 \\
& & & & 249 \\
\hline \# of banks
\end{tabular}

Note: The change in the unemployment rate $(\Delta \mathrm{Urd})$ and the change in per capita income rate ( $\triangle \mathrm{Pcir}$ ) is exactly same for the two groups since the banks in the two groups have been matched based on geographical location.

$\Delta$ Size $=$ change in the size of the bank from year $(-1)$ to year $(+1)$

$\Delta$ Equityr $=$ change in the equity ratio of the bank from year $(-1)$ to year $(+1)$

$\Delta \mathrm{Urd}=$ change in the unemployment rate of the county in which the bank is located from year $(-1)$ to year $(+1)$

$\Delta \mathrm{Pcir}=$ change in the per capita income of the county in which the bank is located from year $(-1)$ to year $(+1)$

$\Delta$ Reloan $=$ change in the proportion of real estate loans of the bank from year $(-1)$ to year $(+1)$

$\Delta$ Delinqr $=$ change in the proportion of delinquent loans of the bank from year $(-1)$ to year $(+1)$ 
Table 2: Comparison of Subchapter S and non-Subchapter S banks: univariate analysis

This table presents the mean and standard deviation of the changes in the variables of interest for the Subchapter $\mathrm{S}$ banks and the matched sample of non-Subchapter S banks. Difference-in- differences are shown in column 3 with respective $p$-values. *,** and $* * *$ denote significant differences between the samples means at the $10 \%, 5 \%$ and $1 \%$ levels respectively.

\begin{tabular}{|c|c|c|c|c|c|c|}
\hline \multirow[b]{2}{*}{ Variable } & \multicolumn{2}{|c|}{ Subchapter S banks } & \multicolumn{2}{|c|}{ Non Subchapter S banks } & \multicolumn{2}{|c|}{ Sub S-Non Sub S } \\
\hline & Mean & Std Dev & Mean & Std Dev & Difference & $p$-value \\
\hline$\Delta$ Spread & -0.0005 & 0.0355 & -0.0031 & 0.0382 & 0.0026 & 0.4367 \\
\hline$\Delta \mathrm{Adr}$ & -0.0059 & 0.0359 & -0.0034 & 0.0365 & -0.0025 & 0.4383 \\
\hline$\Delta$ Alr & -0.0064 & 0.0115 & -0.0065 & 0.0127 & 0.0001 & 0.9254 \\
\hline$\Delta$ Growth & -0.0022 & 0.0108 & -0.0008 & 0.0156 & -0.0013 & 0.2774 \\
\hline$\Delta \mathrm{W}$ stexp & 0.0296 & 0.0614 & 0.0305 & 0.0621 & -0.0009 & 0.8705 \\
\hline$\Delta$ Optexsal & 0.0058 & 0.0206 & 0.0049 & 0.0186 & 0.0009 & 0.5943 \\
\hline$\Delta \mathrm{Emp}$ & 3.1285 & 13.1538 & 4.6867 & 15.5695 & -1.5582 & 0.2282 \\
\hline$\Delta$ Roe $^{* * *}$ & 4.7589 & 5.2407 & 0.4957 & 5.0342 & 4.2632 & 0.0001 \\
\hline \# of banks & 249 & & 249 & & & \\
\hline
\end{tabular}

$\Delta$ Spread $=$ change in the spread of the bank from year $(-1)$ to year $(+1)$

$\Delta \mathrm{Alr}=$ change in the average loan rate of the bank from year $(-1)$ to year $(+1)$

$\Delta \mathrm{Adr}=$ change in the average deposit rate of the bank from year $(-1)$ to year $(+1)$

$\Delta$ Growth $=$ change in the growth of assets of the bank from year $(-1)$ to year $(+1)$

$\Delta \mathrm{W}$ stexp $=$ change in the wage, salary and travel expenses for the bank from year $(-1)$ to year $(+1)$

$\Delta$ Optexsal $=$ change in the operating expenses excluding wage and salary expenses for the bank from year $(-1)$ to year $(+1)$

$\Delta$ Emp $=$ change in the number of employees of the bank from year $(-1)$ to year $(+1)$

$\Delta \mathrm{Roe}=$ change in the return on equity of the bank from year $(-1)$ to year $(+1)$ 
Table 3: The effect of Subchapter S Status on stakeholders

This table presents the results of the regression equation with $\Delta \operatorname{Spread}($ in equation 2.1), $\Delta \mathrm{Alr}($ in 2.2$), \Delta \mathrm{Adr}($ in 2.3 ), $\Delta \mathrm{Growth}(\mathrm{in}$ 2.4), $\Delta$ Wstexp(in 2.5), $\Delta$ Optexsal(in 2.6), $\Delta \operatorname{Emp}($ in 2.7) and $\Delta$ Roe(in 2.8) as the dependent variable. Each of the dependent variable is explained in the paper. The regression coefficients on selected variables and their significance for the sample of Subchapter S and non-Subchapter S banks are presented. The independent variables are used to control for change in size, unemployment rate, delinquency ratio, proportion of real estate loans, equity ratio and metropolitan statistical area. Note that the dependent variables are same in each of the equations because our interest is in dummy variable Scode and its significance with respect to the dependent variables. The variable of interest is the Scode dummy, which takes value of 1 for Subchapter S banks, and of 0 for matched sample of non-Subchapter S banks. *, ** and *** denote significance at the $10 \%, 5 \%$ and $1 \%$ levels.

\begin{tabular}{|c|c|c|c|c|c|c|c|c|}
\hline $\begin{array}{l}\text { Equation } \\
\text { Number }\end{array}$ & $(2.1)$ & $(2.2)$ & $(2.3)$ & $(2.4)$ & $(2.5)$ & $(2.6)$ & $(2.7)$ & $(2.8)$ \\
\hline & $\Delta$ Spread & $\Delta \mathrm{Adr}$ & $\Delta \mathrm{Alr}$ & $\Delta$ Growth & $\Delta$ Wstexp & $\Delta$ Optexsal & $\Delta \mathrm{Emp}$ & $\Delta$ Roe \\
\hline Constant & -0.0018 & $-0.0065^{*}$ & $-0.0084 * * *$ & -0.0001 & $0.0399 * * *$ & $0.0089 * * *$ & -1.7862 & -1.1287 \\
\hline Scode & 0.0022 & -0.0019 & 0.0003 & -0.0007 & -0.0029 & 0.0003 & -1.4725 & $4.3347 * * *$ \\
\hline$\Delta$ Size & $-0.0525^{* *}$ & $0.0503 * *$ & -0.0021 & $0.047 * * *$ & $-0.1280 * * *$ & $-0.0554 * * *$ & $97.8427 * * *$ & $12.4743 * * *$ \\
\hline$\Delta$ Equityr & $-0.1350 * *$ & 0.057 & $-0.078 * * *$ & $-0.1647 * * *$ & 0.1434 & 0.036 & $147.5632 * * *$ & -5.2599 \\
\hline$\Delta \mathrm{Urd}$ & $-0.0060 * * *$ & 0.0021 & $-0.0039 * * *$ & -0.0003 & $0.0256 * * *$ & $0.0058 * * *$ & 0.3085 & $-0.5103 * *$ \\
\hline$\Delta \mathrm{Pcir}$ & 0.000001 & 0.000000 & $0.000001 * * *$ & 0.000000 & $-.000004 * *$ & $-0.000001 * * *$ & -0.000449 & $0.000406^{* *}$ \\
\hline$\Delta$ Reloan & 0.0224 & -0.0388 & $-0.0163 * *$ & $-0.0431 * * *$ & 0.0635 & 0.0094 & 14.3276 & $8.1868 * *$ \\
\hline Mcode & 0.0009 & 0.0003 & 0.0012 & -0.0014 & -0.0031 & 0.0025 & 0.5431 & -0.2512 \\
\hline$\Delta$ Delinqr & $0.5446^{*}$ & -0.1978 & $0.3467 * * *$ & -0.0054 & $-0.7730 * * *$ & $-0.2490 * *$ & -57.0217 & -46.7236 \\
\hline \#of Obs & 498 & 498 & 498 & 498 & 498 & 498 & 498 & 498 \\
\hline R-Squared & 0.0673 & 0.0208 & 0.2671 & 0.1642 & 0.3126 & 0.2489 & 0.2656 & 0.2446 \\
\hline
\end{tabular}


CHAPTER 3: ESSAY 2

\section{A COMPARISON OF CREDIT UNIONS AND SUBCHAPTER S BANKS: WHO SHARES HIGHER TAX BENEFIT WITH CUSTOMERS?}

\subsection{Introduction}

The Federal Credit Union Act of 1934 establishes credit unions as institutions that provide financial services to people with limited access and limited means. The federal credit unions are exempted from federal income tax and do not pay taxes on the retained earnings. The Small Business Job Protection Act of 1996 allows banks to convert to Scorporations and avoid double taxation just like credit unions. However, unlike credit unions, the shareholders of the Subchapter S banks have to pay taxes on the retained earnings. The credit unions have defended their special tax exemption of retained earnings on the pretext of their not-for-profit nature and claims that credit unions have a special purpose of serving individuals of limited means.

In this essay we compare credit unions and Subchapter S banks to investigate who does a better job in passing a portion of the tax benefits to its customers. In the absence of any direct measurement of the flow of tax subsidy we rely on proxies to measure if the benefits are passed on to the customers or are used to support inefficient operations. That is, if the benefits are passed to the borrowers they will benefit in the form of lower loan rates and depositors receiving higher rates on their deposits. Furthermore, the customers will supposedly benefit if the service fee charges are lower. We further investigate if tax exemptions are used to support inefficient operations by comparing the return on equity, return on assets, wage-salary-travel expenses as well as operating expenses. Higher 
wage-salary-travel expenses and higher operating expenses would mean that tax benefit has been directed to support operations. A lower return on equity as well as on assets would indicate inefficient operations.

The supporters of tax exemption to credit unions argue that credit unions have provided a valuable alternative to the for-profit banking system and serves people who have no or limited access to other financial services ${ }^{6}$.However, the American Bankers Association argues that Subchapter-S banks, unlike credit unions, still must pay taxes on retained earnings and demands that credit unions should also be taxed on the retained earnings. ${ }^{7}$ The credit unions assert that the portion of the institution's retained earnings is used to meet the capital requirements or capital adequacy ratios ${ }^{8}$. Credit unions also argue that if credit unions lose their tax-exempt status, credit unions will have to pass along the burden of tax payments to their members ${ }^{9}$. The findings of our paper have significant policy implications, as the tax exemption to credit unions is being questioned and scrutinized. The Tax Reform Subcommittee of the President's Economic Recovery Advisory Board (PERAB) has listed the option of eliminating tax expenditures like the credit union federal income tax exemption as one of the options for reforming corporate $\operatorname{taxation}^{10}$

\footnotetext{
${ }^{6}$. U.S. Department of the Treasury “Comparing Credit Unions and Other Depository Institutions", January 2001. Page 28.)

${ }^{7}$ American Bankers Association, 2009. Subchapter S Banks vs. Credit Unions: An Unfair CU Tax Advantage. Position paper on http://www.aba.com

8 http://www.cuna.org/gov_affairs/legislative/issues/download/sub_s_banks.pdf 9 http://www.cuna.org/gov_affairs/download/Why_CUs_TaxExempt09.pdf

10 http://www.treasury.gov/press-center/press-releases/Pages/report3070.aspx
} 
Our results indicate that in comparison to the Subchapter S banks the credit unions have lower deposit rates and higher loan rates. We also find that the fee structure of credit unions is not customer friendly as compared to Subchapter S banks. Moreover, credit unions have lower return on equity as well as on assets compared to Subchapter S banks. We also find that the credit unions have higher operating expenses as compared to Subchapter S banks. Overall, we find that compared to credit unions, Subchapter S banks do a better job in passing the tax benefits to their customers.

The remainder of the paper is organized as follows. In section 2, we provide the relevant literature and discuss the research questions. In section 3, we present the details about the sample construction and variables of interest. In section 4, we present the methodology. Section 5 has the results. In section 6, we present the conclusion.

\subsection{Literature Review}

According to Rose (1994) credit unions are granted tax-exempt status so that credit union members receive the benefit of the tax subsidy. Credit unions have also claimed that they pass on the tax subsidy to its customers and if they (credit unions) lose their tax-exempt status, they will have to pass along their tax burden to their members. Prior research has been limited in scope and size. As far as we know in this study we are the first to compare the various attributes of tax exempted federally chartered credit unions with their counter parts of Subchapter S banks which have similar tax exemptions. Yvonne, Hinson and Juras (2002) argue that the credit unions are granted tax-exempt status so that they offer lower loan rates and higher deposit rates to its members. They compare the net interest margin of the credit unions with mutual loans and savings for the 
year 1993 and 1994 and find that credit unions are not passing along a significant portion of their tax subsidy to members through lower interest margins but the authors did not specifically investigate the difference in the loan and deposit rates of the two institutions. Our study is more comprehensive as we investigate the loan/deposit rates over a longer period of time.

Frame, Karels and McClatchey (2003) estimate a translog cost function for credit unions and mutual thrifts to examine if the credit unions pass the tax benefits to its customers or engage in expense preference behavior relative to mutual thrifts. They classify federal credit unions on the basis of common bond of occupation, association, or geographic area. It is interesting to note that the membership at credit unions is based on affinity among members or a common bond ${ }^{11}$. The membership at occupational credit unions is limited to individuals sharing a common employer. The members of associational credit unions include members of a religious group or a civic group. The membership at residential or community credit unions is limited to individuals of a particular residential area or community. Their results are interesting as they find that credit union industry, as a whole does not exhibit expense preference behavior. They find that credit unions with residential common bonds have higher costs than mutual thrifts, but single common bond occupational and associational credit unions are more cost efficient. Our study extends their work beyond mutual thrifts and credit unions as we compare member owned credit unions with privately owned Subchapter S banks.

\footnotetext{
${ }^{11}$ Frame, W. S., Karels, G.V., McClatchey, C. "The Effect of the Common Bond and Membership Expansion on Credit Union Risk”. Federal Reserve Bank of Atlanta. 2001
} 
Depken, Hollans, and Swidler (2010) compare the rates for individual products for the Subchapter $\mathrm{S}$ banks, credit unions and $\mathrm{C}$ banks by using the second quarter data for the year 2008 and find that Subchapter-S deposit (loan) rates are equal to or lower (higher) than similar $\mathrm{C}$ corporation bank rates. They also find that that credit unions offer higher deposit rates on certain products but overall the results are inconclusive. In this paper we compare the credit unions and the Subchapter S banks over a period of six years from 2005 to 2010 . We compare the interest rate spread, average loan as well as average deposit rates for the credit unions and Subchapter S banks. We then investigate if the credit union charge lower service fee to its customers as compared to Subchapter S banks. We contrast the performance of credit unions with Subchapter S banks by comparing the return on equity as well as on assets. We also investigate if credit unions have higher wage/salary and or operating expenses as compared to Subchapter S banks.

\subsection{Data}

We collect the data on Subchapter S banks from Highline Financial database and the data for credit unions from the website of National Credit Union Administration (NCUA). To make an even comparison we create a subsample of the federally chartered credit unions and Subchapter S banks that have a similar customer base and market level competition. In our sample we match the credit unions with Subchapter S banks based on state code and county code. We find that in our period of study, quite a number of credit unions are small without comparable Subchapter S banks. Similarly on the other side the time period of our study consists of some credit unions that are bigger than a comparable Subchapter S bank. Therefore, we delete institutions below $\$ 50$ million and above $\$ 3$ 
billion from the population of credit unions and Subchapter S banks. We include only those counties that have at least one credit union and one Subchapter S bank. In our multivariate regressions we control for local economic factors.

We collect all the relevant data from the following sources;

1. Per capita income by county from the website of the US Department of Commerce, Bureau of Economic Analysis

2. Unemployment rate from the website of US Department of Labor, Bureau of Labor Statistics.

The following is the description of variables used in this study:

- Size $=\log$ of total assets

- Average loan rate $(\mathrm{Alr})=$ interest and fee income on loans/total loans and leases

- Average deposit rate $(\mathrm{Adr})=$ total interest expense/total deposits

- Spread $=$ average loan rate-average deposit rate

- Optexp = operating expenses/total expenses

- Wstexp(wage salary and travel expenses) $=$ non interest expense (salary and employee benefits)/total expenses

- $\mathrm{Urr}=$ the unemployment rate of county in which bank is located

- $\quad$ Lpcir $=$ the log of per capita income of the county in which bank is located

- Scode (dummy variable) $=1$ if bank is Subchapter S, 0 otherwise

- Delequencyratio = total amount of delinquent loans and leases/total amount of loans and leases

\subsection{Methodology}

We use the annual data for the Subchapter S banks and credit unions for the years 2005-2010 for our empirical analysis. We perform both univariate analysis as well as cross-sectional multivariate regressions. 
Univariate Analysis:

Our goal is to test if the relevant attributes for the credit unions $\left(\mu_{1}\right)$ are different from the corresponding attributes of the Subchapter S banks $\left(\mu_{2}\right)$. Hence we test the following null-hypothesis:

$$
H_{0}: \mu_{1}-\mu_{2}=0
$$

Against the alternative hypothesis:

$$
H_{1}: \mu_{1}-\mu_{2} \neq 0
$$

We first determine whether the population variances are statistically equal using the Snedecor's F-test. If we find that the population variances are statistically same then we use the standard two-independent sample t-test to test the null hypothesis posited above. ${ }^{12}$ If, however, we find that the population variances are statistically unequal, we use the two independent sample t-test for equality of population means proposed by Satterthwaite (1946). If the null hypothesis is true, the t-statistic will have Student's tdistribution with Welch's (1947) “modified” degrees of freedom given by;

$$
d f=\frac{\left(\frac{s_{1}^{2}}{n_{1}}+\frac{s_{2}^{2}}{n_{2}}\right)^{2}}{\frac{\left(s_{1}^{2} / n_{1}\right)^{2}}{n_{1}}+\frac{\left(s_{2}^{2} / n_{2}\right)^{2}}{n_{2}}}
$$

\footnotetext{
${ }^{12}$ For the test statistics and procedures to test the equality of two population variances and the equality of two population means when population variances are unknown but equal see any basic standard statistics textbook.
} 
Where $n_{i}$ and $s_{i}^{2}(\mathrm{i}=1,2)$ respectively are the sample size and the sample variance of the $i^{\text {th }}$ sample.

Multivariate Analysis:

Following Mayne (1977) and Thomson (1991), in our multivariate analysis, we use county unemployment rate and the per-capita income to control for local economic factors. Furthermore, we control for the size because economies of scales are experienced by banks and credit unions as they grow larger and it affects the spread and other variables included in our study. We also control for delinquency ratio as it is an indicator of the quality of bank's loan portfolio and is expected to affect the spread and average loan rates for the bank.

In equations (3.1) to (3.8) to we regress a particular dependent variable on over a dummy variable Scode which takes a value of 0 for credit unions and a value of 1 for Subchapter S banks as well as other independent variables e.g., Size, Urr, Lpcir and Delequencyratio. Our variable of interest is the sign and statistical significance of the dummy variable Scode in each case where as the other variables are the control variables, For example in equation (3.1) we investigate the significance of the dummy variable Scode. A positive and significant coefficient on Scode would indicate that the spread for the credit unions is lower.

Spread $=\alpha+\beta_{1}$ Scode $+\beta_{2}$ Size $+\beta_{3}$ Urr $+\beta_{4}$ Lpcir $+\beta_{5}$ Delequency ratio $+\varepsilon$

A difference in the spread does not specifically tell us about the difference in loan or deposit rates, hence we investigate if there is a significant difference between the average loan rate and average deposit rate between the credit unions and Subchapter S 
banks. We use, respectively, equations (3.2) and (3.3) to compare the average loan rates and average deposit rates for the credit unions and Subchapter S banks.

$$
\begin{aligned}
& \text { Alr }=\alpha+\beta_{1} \text { Scode }+\beta_{2} \text { Size }+\beta_{3} \text { Urr }+\beta_{4} \text { Lpcir }+\beta_{5} \text { Delequency ratio }+\varepsilon \\
& \text { Adr }=\alpha+\beta_{1} \text { Scode }+\beta_{2} \text { Size }+\beta_{3} \text { Urr }+\beta_{4} \text { Lpcir }+\beta_{5} \text { Delequency ratio }+\varepsilon
\end{aligned}
$$

Credit unions claim that they charge lower fee as compared to other institutions and argue that if credit unions lose their special tax-exempt status, they will have to pass the tax burden in higher fees to its customers. Equation (3.4) to examine if credit unions have a lower fee structure as compared to Subchapter S banks

$$
\text { Servefee }=\alpha+\beta_{1} \text { Scode }+\beta_{2} \text { Size }+\beta_{3} \text { Urr }+\beta_{4} \text { Lpcir }+\beta_{5} \text { Delequencyratio }+\varepsilon
$$

Credit unions have more diffused ownership structure as compared to Subchapter $\mathrm{S}$ banks and might be operating inefficiently. Each member of a credit union has only one vote and do not have any control over its operations, whereas, in case of Subchapter S banks, the large shareholders have significantly more control over the operations of the bank. This might influence the return on equity and return on assets. We use equations (3.5) and (3.6) to compare the return on equity and return on assets of credit unions with Subchapter S banks.

$$
\begin{aligned}
& \text { Roe }=\alpha+\beta_{1} \text { Scode }+\beta_{2} \text { Size }+\beta_{3} \text { Urr }+\beta_{4} \text { Lpcir }+\beta_{5} \text { Delequency ratio }+\varepsilon \\
& \text { Roa }=\alpha+\beta_{1} \text { Scode }+\beta_{2} \text { Size }+\beta_{3} \text { Urr }+\beta_{4} \text { Lpcir }+\beta_{5} \text { Delequency ratio }+\varepsilon
\end{aligned}
$$

We further investigate if the tax benefits are being directed to pay higher salaries and/ or on higher operating expenses, using the following equation (3.7) and (3.8). 


$$
\begin{aligned}
& \text { Wstexp }=\alpha+\beta_{1} \text { Scode }+\beta_{2} \text { Size }+\beta_{3} \text { Urr }+\beta_{4} \text { Lpcir }+\beta_{5} \text { Delequency ratio }+\varepsilon \\
& \text { Optexp }=\alpha+\beta_{1} \text { Scode }+\beta_{2} \text { Size }+\beta_{3} \text { Urr }+\beta_{4} \text { Lpcir }+\beta_{5} \text { Delequency ratio }+\varepsilon
\end{aligned}
$$

\subsection{Results and Analysis}

In Table 4, we present the descriptive statistics for the size, spread, average loan rate, average deposit rate, service fee, return on equity and return on assets, wage-salarytravel expenses and operating expenses. Our screened sample contains 1602 credit unions and 1450 Subchapter $\mathrm{S}$ banks during the period of study ${ }^{13}$. We include only those counties that have at least one credit union and one Subchapter S bank. The number of Subchapter S banks and credit unions is different in some counties therefore the sample sizes for credit Unions and Subchapter S banks are not same. The size of the credit unions included in the sample varies from $\$ 50.05 \mathrm{M}$ to $\$ 2.95 \mathrm{~B}$ whereas the size of the Subchapter $\mathrm{S}$ banks varies from $\$ 50 \mathrm{M}$ to $\$ 2.93 \mathrm{~B}$. The mean spread for the credit unions and Subchapter S banks are respectively 6.18 and 6.16 percent. The average loan rate for credit unions is 8.44 percent and for the Subchapter S banks, 8.74 percent. The average deposit rate is 2.26 percent for the credit unions and 2.57 percent for Subchapter S banks. The mean wage-salary-and travel expenses at credit unions are 32.90 percent of total expenses and for Subchapter S banks it is 32.52 percent. The average operating expenses at Subchapter S banks and credit unions are respectively 8.24 percent of and 15.61 percent of the total expenses. The mean return on equity for credit unions is 6.67 percent as compared to 14.09 percent for Subchapter S banks. The average return on assets is 1.38 percent for Subchapter S banks whereas it is only 0.75 percent for credit unions.

\footnotetext{
${ }^{13}$ The sample contains only those institutions which have total assets between $\$ 50$ million and $\$ 3$ billion.
} 
In Table 5, we present the univariate analysis of the variables of interest during the period 2005 to 2010 and for each of the individual years. We find that the spread for the credit unions is not significantly different from the Subchapter $\mathrm{S}$ banks for the overall period 2005 to 2010 . However, yearly comparisons yield mixed results. The spread is higher for the credit unions in year 2005 whereas the spread is lower for the credit unions in the year 2008 and 2010. We find that the average loan rate is lower for Subchapter S banks for the period 2005 to 2010 . As regards yearly comparisons, average loan rate is lower for Subchapter S banks in the year 2005, 2006 and 2007. There is no significant difference in the years 2008 and 2009. However, Average loan rate is higher for Subchapter S banks in the year 2010. The average deposit rate is lower for Subchapter S banks for the period 2005 to 2010.As regards yearly comparisons; the average deposit rate is lower for Subchapter S banks in each year except in 2009 when there is no statistically significant difference.

We find that the return on equity and return on assets for the credit unions is lower than the Subchapter S banks for the period 2005 to 2010 as well as for each of the years. The wage salary expenses for the two groups are not significantly different from each other except for year 2006 and 2007 when wage salary expenses are higher for Subchapter S banks. Finally, the operating expenses for the credit unions are higher as compared to Subchapter S banks for the period 2005 to 2010 and for each of the individual years.

In Table 6, we present the results of the regression analysis on the variables of interest reported in Table 5. Each of the variables Spread, Alr, Adr, Servefee, Roe, Roa, Wstexp and Optexp are regressed on the set of control variables and the Scode dummy 
which takes value of 1 for the sample of Subchapter S banks, and of 0 for matched sample of federally chartered credit unions. The independent variables are used to control for size, unemployment rate, and delinquency ratio.

We find the coefficient on Scode to be statistically insignificant in spread regression (equation 3.1), indicating that there is no difference in the spread of the credit unions and Subchapter S banks.

We find the coefficient on Scode to be positive and significant for the regression (equation 3.2) indicating that the average loan rate is higher for Subchapter S banks as compared to credit unions. The results suggest that credit unions offer lower loan rates as compared to Subchapter S banks.

We find the coefficient on Scode to be positive and significant for the regression (equation 3.3), indicating that the average deposit rate is higher for Subchapter S banks for the period 2005 to 2010 . The results suggest that credit unions offer lower deposit rates as compared to Subchapter S banks.

The coefficient on Scode is negative and significant for Servefee regression (equation 3.4) which indicates that the credit unions on an average charge higher service fee to its customers. The findings contradict the claim of the credit unions that they charge lower service fee to its customers.

We regress the return on equity (Roe) on the Scode dummy and the set of control variables (equation 3.5). We find that the coefficient on Scode is positive and significant. The regression results indicate that the return on equity for the credit unions is significantly less than that for Subchapter S banks. The coefficient on Scode is positive and significant for the return on assets (Roa) regression (equation 3.6) which indicates 
that the return on assets for the credit unions is significantly less than that for Subchapter S banks.

The results for wage, salary and travel expenses regression (equation 3.7) indicates that there is no difference in the salaries of the employees of the credit unions and Subchapter S banks as the coefficient on Scode is insignificant.

The results for the operating expense regression (equation 3.8) indicates that the operating expenses for the credit unions is higher as compared to Subchapter S banks as the coefficient on Scode is negative and significant. The higher operating expenses for the credit unions indicate inefficient operations.

\subsection{Robustness Tests}

It may be argued that our results are driven by large sample size. Hence, in order to mitigate the large sample size problem we conduct a series of regressions on the variables of interest for each year separately.

In Table 7, we present the results of regression analysis on Spread for each year from 2005 to 2010. The Spread is significantly higher at Subchapter S banks in the year 2006 and 2007. There is no difference in the spread in the year 2005, 2008 and 2009. However the spread is significantly higher for credit Unions in the year 2010. The results indicate that in 2010 the difference between the average loan rate and average deposit rate is higher for the credit union as compared to that of Subchapter S banks.

In Table 8, we present the results of regression analysis on average loan rate (Alr). We find that the average loan rate is higher for Subchapter S banks in the year 2005, 2006 and 2007. These results are consistent with the results for the combined period from 
2005 to 2010. However, in the year 2008 and 2009, we find no significant difference in the average loan rate for credit unions and Subchapter S banks. We find that in the year 2010, the average loan rate is higher for credit unions. The results indicate that credit unions used to offer lower loan rates but not anymore. In Table 9, we present the results of regression analysis on average deposit rate (Adr) for each year from 2005 to 2010. The results indicate that the average deposit rate offered by credit unions is lower for the year 2005, 2006, 2007, 2008, 2010 and for 2009, there was no significant difference. The regression results for the combined period from 2005 to 2010 and yearly regressions are consistent. We find that Subchapter S banks are doing a better job of sharing the tax benefit with the depositors in the form of higher deposit rates.

In Table 10, we present the results of regression analysis on Service fee (Servefee) for each year from 2005 to 2010 . The results indicate that the service fee charged by credit unions is higher for each of the years 2005, 2006, 2007, 2008, 2009 and 2010. The yearly regression results are consistent with the results for the combined period from 2005 to 2010. We find that credit unions charge higher service fee than Subchapter S banks.

In Table 11, we present the results of regression analysis on wage, salary and travel expenses (Wstexp) for each year from 2005 to 2010. The results indicate that there was no statistically significant difference in the wage salary and travel expenses for the year 2005, 2008, 2009 and 2010. However, it was higher in 2006 and 2007 for credit unions. We find that the wage salary and travel expenses for the credit unions are similar to that for Subchapter S banks. 
In Table 12, we present the results of regression analysis on operating expenses (Optexp) for each year from 2005 to 2010 . The results indicate that the operating expenses are higher for credit unions for each year from 2005 to 2010. The yearly regression results are consistent with the regression results for the combined period from 2005 to 2010.

In Table 13, we present the results of regression analysis on return on equity (Roe) for each year from 2005 to 2010. The yearly regression results are presented in Table 10. The results for each of the individual years from 2005 to 2010 indicate that Subchapter S banks have significantly higher return on equity as compared to credit unions.

In Table 14, we present the results of regression analysis on return on assets for each year from 2005 to 2010. The results confirm that credit unions have lower return on assets as compared to Subchapter S banks. The yearly regression results of return on equity and return on assets are consistent and support the regression results for the overall period from 2005 to 2010 .

\subsection{Conclusion}

In this essay we compare not for profit credit unions with for profit Subchapter S banks to investigate which of the two is doing a better job of sharing the tax benefit with its customers. We conduct the analysis for the overall period from 2005- 2010 as well as for each of the individual years separately.

We find that the credit unions do not offer lower loan rates or higher deposit rates as compared to Subchapter S banks. The credit union customers pay a higher service fee as compared to the customers of Subchapter S banks. We find that the operating expenses 
are higher for credit unions indicating inefficient operations. The return on equity and return on assets is significantly higher for Subchapter S banks as compared to credit unions indicating inefficient operations and poor asset utilization at credit unions. Overall, we find that in comparison with credit unions, the Subchapter S banks are doing a superior job at sharing the tax benefit with their customers. 
Table 4: Descriptive statistics for credit unions and Subchapter S banks

In the following table, we present the descriptive statistics for credit unions and Subchapter S banks. We match the credit unions and Subchapter S banks based on the location to control for demographic factors. Our sample is from 2005 to 2010.

\begin{tabular}{|c|c|c|c|c|c|c|c|c|}
\hline \multicolumn{5}{|c|}{ credit unions } & \multicolumn{4}{|c|}{ Subchapter S banks } \\
\hline Variable & Mean & Std Dev & Minimum & Maximum & Mean & Std Dev & Minimum & Maximum \\
\hline Size & 306425788 & 436205768 & 50055000 & 2952342000 & 327438358 & 402631424 & 50001000 & 2928263000 \\
\hline Spread & 0.0618345 & 0.0233059 & 0.015813 & 0.1822686 & 0.0616601 & 0.021368 & 0.0153453 & 0.1862539 \\
\hline Alr & 0.0844655 & 0.0228504 & 0.0473648 & 0.1984057 & 0.0874353 & 0.0209242 & 0.0323722 & 0.1989043 \\
\hline Adr & 0.022631 & 0.0072495 & 0.010007 & 0.0551008 & 0.0257752 & 0.0100684 & 0.0100059 & 0.0898747 \\
\hline Servefee & 0.0153367 & 0.010567 & 0 & 0.0802977 & 0.0048679 & 0.0173902 & 0 & 0.4545164 \\
\hline Wstexp & 0.3290988 & 0.0653102 & 0.000099875 & 0.5583958 & 0.3252256 & 0.0780289 & 0.0516056 & 0.5793951 \\
\hline Optexp & 0.156186 & 0.0528422 & 0.0149127 & 0.3773304 & 0.0824777 & 0.0309486 & 0.0063716 & 0.1964962 \\
\hline Roe & 0.0667276 & 0.0408156 & 0 & 0.4239171 & 0.1409807 & 0.0831974 & 0 & 0.5856814 \\
\hline Roa & 0.0075564 & 0.0046757 & 0 & 0.0420052 & 0.0138001 & 0.0084551 & 0 & 0.0647041 \\
\hline \# of Obs & 1602 & & & & 1450 & & & \\
\hline
\end{tabular}

Description of variables

Size $=$ Total assets

Spread $=$ average loan rate-average deposit rate

Alr $=$ average loan rate

Adr $=$ average deposit rate

Servefee $=$ service fee and charges
Wstexp $=$ wage salary and travel expenses

Optexp $=$ operating expenses

Roe $=$ return on equity

Roa $=$ return on assets 
Table 5: Comparison of credit unions and Subchapter S banks: univariate analysis

In the following table, we present the univariate comparisons of credit unions and Subchapter S banks from Table 4. We present the results of t-tests on the differences in the means of the variables of interest for the period 2005 to 2010 and for each of the Individual years. $*, * *$ and $* * *$ denote, respectively $10 \%, 5 \%$ and $1 \%$ levels of significance.

\begin{tabular}{|c|c|c|c|c|c|c|c|}
\hline \multirow[b]{2}{*}{ Variable } & \multicolumn{6}{|c|}{ Differences between the Means(credit unions-Subchapter S banks) } & \multirow[b]{2}{*}{2010} \\
\hline & $2005-2010$ & 2005 & 2006 & 2007 & 2008 & 2009 & \\
\hline Spread & 0.0002 & -0.0006 & $-0.0046^{*}$ & -0.0027 & $0.0032 *$ & 0.0029 & $0.0072 * * *$ \\
\hline Alr & $-0.003 * *$ & $-0.0029^{*}$ & $-0.0097 * * *$ & $-0.0081 * * *$ & 0.002 & 0.0028 & $0.0055^{* *}$ \\
\hline Adr & $-0.0031 * * *$ & $-0.0023 * * *$ & $-0.005 * * *$ & $-0.0054 * * *$ & $-0.0013 * * *$ & -0.0001 & $-0.0017 * * *$ \\
\hline Servefee & $0.0105^{* * *}$ & $0.0088 * * *$ & $0.0081 * * *$ & $0.0088 * * *$ & $0.0155 * *$ & $0.011 * * *$ & $0.0111 * * *$ \\
\hline Roe & $-0.0743 * * *$ & $-0.099 * * *$ & $-0.1025 * * *$ & $-0.084 * * *$ & $-0.0585 * * *$ & $-0.0347 * * *$ & $-0.0404 * * *$ \\
\hline Roa & $-0.0062 * * *$ & $-0.0082 * * *$ & $-0.0087 * * *$ & $-0.0071 * * *$ & $-0.0046^{* * *}$ & $-0.0033 * * *$ & $-0.0037 * * *$ \\
\hline Wstexp & 0.0039 & -0.0069 & $0.0129 * *$ & $0.0132 * *$ & -0.0015 & 0.0008 & -0.0098 \\
\hline Optexp & $0.0737 * * *$ & $0.0789 * * *$ & $0.0774 * * *$ & $0.0742 * * *$ & $0.0696 * * *$ & $0.0676^{* * *}$ & $0.0689 * * *$ \\
\hline
\end{tabular}

Description of variables

Spread $=$ average loan rate-average deposit rate

Alr $=$ average loan rate

$\mathrm{Adr}=$ average deposit rate

Servefee $=$ service fee and charges
Roe $=$ return on equity

Roa $=$ return on assets

Wstexp $=$ wage salary and travel expenses

Optexp $=$ operating expenses 
Table 6: Comparison of credit unions and Subchapter S banks for the period 2005-2010

In this table, we present the results for the regression of variables of interest on size, unemployment rate, per capita income, delinquency ratio and a dummy variable for credit unions (dummy=0) and Subchapter S banks (dummy=1). We present the results for the period 2005-2010. The following acronyms are used: Size (log (total assets)), Lpcir (log (per capita income)), Urr (unemployment rate), and Delequencyratio (delinquent loans/total loans). $*$, ** and $* * *$ denote, respectively $10 \%, 5 \%$ and $1 \%$ levels of significance.

\begin{tabular}{|c|c|c|c|c|c|c|c|c|}
\hline \multicolumn{9}{|c|}{ Regression results 2005-2010 } \\
\hline & Spread & Alr & $\mathrm{Adr}$ & Servefee & Wstexp & Optexp & Roe & Roa \\
\hline \multicolumn{9}{|c|}{ Independent Variables: } \\
\hline Constant & $0.1374 * * *$ & $0.1288 * * *$ & -0.0087 & $0.1043 * * *$ & $0.8814 * * *$ & $0.4518^{* * *}$ & $0.3641 * * *$ & $0.0253 * * *$ \\
\hline Scode & 0.0006 & $0.0034 * * *$ & $0.0028 * * *$ & $-0.0107 * * *$ & -0.0014 & $-0.0738 * * *$ & $0.0719 * * *$ & $0.006^{* * *}$ \\
\hline Size & $-0.004 * * *$ & $-0.0033 * * *$ & $0.0007 * * *$ & 0.0002 & $-0.0075 * * *$ & $-0.0019 * *$ & $0.0106^{* * *}$ & $0.0008 * * *$ \\
\hline Urr & 0.0002 & $-0.0013 * * *$ & $-0.0015 * * *$ & 0 & $0.0036^{* * *}$ & 0.0004 & $-0.0072 * * *$ & $-0.0007^{* * *}$ \\
\hline Lpcir & -0.0001 & 0.0024 & $0.0025 * * *$ & $-0.0087 * * *$ & $-0.0407 * * *$ & $-0.0247 * * *$ & $-0.0434 * * *$ & $-0.0028 * * *$ \\
\hline Delequencyratio & 0.0001 & 0.0008 & $0.0007 * *$ & -0.0005 & $-0.0107 * * *$ & -0.0018 & $-0.0082 * * *$ & -0.0005 \\
\hline \# of Obs & 3045 & 3045 & 3045 & 3045 & 3045 & 3045 & 3045 & 3045 \\
\hline R-Squared & 0.0272 & 0.039 & 0.1519 & 0.1362 & 0.0409 & 0.4261 & 0.3156 & 0.2264 \\
\hline
\end{tabular}

\section{Description of variables}

Spread $=$ average loan rate-average deposit rate

Alr $=$ average loan rate

Adr $=$ average deposit rate

Servefee $=$ service fee and charges
Roe $=$ return on equity

Roa $=$ return on assets

Wstexp $=$ wage salary and travel expenses

Optexp $=$ operating expenses 
Table 7: Comparison of credit unions and Subchapter S banks: Spread

In this table we present the results for the regression of spread on size, unemployment rate, per capita income, delinquency ratio and a dummy variable for credit unions (dummy=0) and Subchapter S banks (dummy=1). We present the results for each Individual year from 2005 to 2010. The following acronyms are used: Size (log (total assets)), Lpcir (log (per capita income)), Urr (unemployment rate), and Delequencyratio (delinquent Loans/total Loans). *, ** and *** denote, respectively 10\%, 5\% and 1\% levels of significance.

\begin{tabular}{|c|c|c|c|c|c|c|}
\hline \multicolumn{7}{|c|}{ Regression results for Spread } \\
\hline & 2005 & 2006 & 2007 & 2008 & 2009 & 2010 \\
\hline \multicolumn{7}{|c|}{ Independent Variables: } \\
\hline Constant & $0.1587 * * *$ & 0.0488 & $0.1045^{* *}$ & $0.2065 * * *$ & 0.0839 & 0.0126 \\
\hline Scode & 0.0001 & $0.0063 * * *$ & $0.0035^{*}$ & -0.0022 & -0.0019 & $-0.0066 * * *$ \\
\hline Size & $-0.0042 * * *$ & $-0.004 * * *$ & $-0.0047 * * *$ & $-0.0043 * * *$ & $-0.0035^{* * *}$ & $-0.0022 *$ \\
\hline Urr & $0.0018^{* *}$ & 0.0015 & 0.0009 & 0.0003 & 0.0003 & $0.0018 * * *$ \\
\hline Lpcir & -0.0024 & $0.0077 * *$ & 0.004 & -0.0062 & 0.0039 & 0.0074 \\
\hline Delequencyratio & 0.0059 & 0.0007 & 0.0015 & 0.0002 & -0.0013 & -0.001 \\
\hline$\#$ of Obs & 520 & 593 & 660 & 597 & 373 & 303 \\
\hline R-Squared & 0.0477 & 0.0464 & 0.0378 & 0.0392 & 0.0325 & 0.0758 \\
\hline
\end{tabular}


Table 8: Comparison of credit unions and Subchapter S banks: average loan rate (Alr)

In this table we present the results for the regression of average loan rate on size, unemployment rate, per capita income, delinquency ratio and a dummy variable for credit unions (dummy=0) and Subchapter S banks (dummy=1). We present the results for each Individual year from 2005 to 2010. The following acronyms are used: Size (log (total assets)), Lpcir (log (per capita income)), Urr (unemployment rate), and Delequencyratio (delinquent loans/total loans). *, ** and *** denote, respectively $10 \%, 5 \%$ and $1 \%$ levels of significance.

\begin{tabular}{|c|c|c|c|c|c|c|}
\hline \multicolumn{7}{|c|}{ Regression results for Alr } \\
\hline & 2005 & 2006 & 2007 & 2008 & 2009 & 2010 \\
\hline \multicolumn{7}{|c|}{ Independent Variables: } \\
\hline Constant & $0.1363 * * *$ & 0.0164 & $0.0804^{*}$ & $0.202 * * *$ & $0.1081^{*}$ & 0.0192 \\
\hline Scode & 0.0025 & $0.0111 * * *$ & $0.0085^{* * *}$ & -0.0011 & -0.0019 & $-0.0051 * *$ \\
\hline Size & $-0.0035 * * *$ & $-0.0028 * * *$ & $-0.0033 * * *$ & $-0.0039 * * *$ & $-0.0031 * * *$ & $-0.0021 *$ \\
\hline Urr & $0.002 * *$ & $0.0016^{*}$ & $0.0016^{*}$ & $0.0012 *$ & 0.0004 & $0.0018 * * *$ \\
\hline Lpcir & 0 & $0.0108 * * *$ & $0.0061 *$ & -0.0046 & 0.0027 & 0.0079 \\
\hline Delequencyratio & 0.0061 & 0.0009 & 0.0023 & 0.0015 & -0.001 & -0.0003 \\
\hline \# of Obs & 520 & 593 & 660 & 597 & 373 & 303 \\
\hline R-Squared & 0.0444 & 0.0845 & 0.0582 & 0.0399 & 0.028 & 0.0611 \\
\hline
\end{tabular}


Table 9: Comparison of credit unions and Subchapter S banks: average deposit rate (Adr)

In this table we present the results for the regression of average deposit rate on size, unemployment rate, per capita income, delinquency ratio and a dummy variable for credit unions (dummy=0) and Subchapter S banks (dummy=1). We present the results for each Individual year from 2005 to 2010. The following acronyms are used: Size (log (total assets)), Lpcir (log (per capita income)), Urr (unemployment rate), and Delequencyratio (delinquent loans/total loans). *, ** and *** denote, respectively $10 \%, 5 \%$ and $1 \%$ levels of significance.

\begin{tabular}{|c|c|c|c|c|c|c|}
\hline \multicolumn{7}{|c|}{ Regression results for Adr } \\
\hline & 2005 & 2006 & 2007 & 2008 & 2009 & 2010 \\
\hline \multicolumn{7}{|c|}{ Independent Variables: } \\
\hline Constant & $-0.0225 * *$ & $-0.0324 * *$ & -0.0241 & -0.0045 & 0.0242 & 0.0065 \\
\hline Scode & $0.0024 * * *$ & $0.0048 * * *$ & $0.0049 * * *$ & $0.0011^{*}$ & 0 & $0.0015 * * *$ \\
\hline Size & $0.0007 * * *$ & $0.0012 * * *$ & $0.0014 * * *$ & 0.0004 & 0.0004 & 0.0001 \\
\hline Urr & 0.0001 & 0.0002 & $0.0007 * *$ & $0.0009 * * *$ & 0.0001 & 0 \\
\hline Lpcir & $0.0025 * *$ & $0.0031 * *$ & 0.0022 & 0.0017 & -0.0012 & 0.0005 \\
\hline Delequencyratio & 0.0002 & 0.0002 & 0.0008 & 0.0013 & 0.0003 & $0.0007^{*}$ \\
\hline$\#$ of Obs & 520 & 593 & 660 & 597 & 373 & 303 \\
\hline R-Squared & 0.0752 & 0.139 & 0.1295 & 0.0373 & 0.0065 & 0.0407 \\
\hline
\end{tabular}


Table 10: Comparison of credit unions and Subchapter S banks: Servefee

In this table we present the results for the regression of service fee on size, unemployment rate, per capita income, delinquency ratio and a dummy variable for credit unions (dummy=0) and Subchapter $\mathrm{S}$ banks (dummy=1). We present the results for each Individual year from 2005 to 2010. The following acronyms are used: Size (log (total assets)), Lpcir (log (per capita income)), Urr (unemployment rate), and Delequencyratio (delinquent loans/total loans). *, ** and *** denote, respectively 10\%, 5\% and 1\% levels of significance.

\begin{tabular}{|c|c|c|c|c|c|c|}
\hline \multicolumn{7}{|c|}{ Regression results for Servefee } \\
\hline & 2005 & 2006 & 2007 & 2008 & 2009 & 2010 \\
\hline \multicolumn{7}{|c|}{ Independent Variables: } \\
\hline Constant & $0.1123^{* * *}$ & $0.0799 *$ & $0.0949 * * *$ & $0.091 * * *$ & $0.1095 * * *$ & $0.1407 * * *$ \\
\hline Scode & $-0.0092 * * *$ & $-0.0085 * * *$ & $-0.009 * * *$ & $-0.0157 * * *$ & $-0.011 * * *$ & $-0.0109 * * *$ \\
\hline Size & -0.0003 & 0.001 & 0.0007 & -0.0003 & 0 & 0 \\
\hline Urr & $0.0007 *$ & 0.0013 & 0 & -0.0002 & -0.0001 & -0.0001 \\
\hline Lpcir & $-0.009 * * *$ & $-0.0085^{* *}$ & $-0.0088 * * *$ & $-0.0064 * * *$ & $-0.0088 * * *$ & $-0.0118 * * *$ \\
\hline Delequencyratio & -0.0005 & -0.0002 & -0.0013 & -0.0002 & -0.0005 & -0.0003 \\
\hline \# of Obs & 520 & 593 & 660 & 597 & 373 & 303 \\
\hline R-Squared & 0.2575 & 0.2677 & 0.0626 & 0.5452 & 0.3273 & 0.34 \\
\hline
\end{tabular}


Table 11: Comparison of credit unions and Subchapter S banks: Wstexp

In this table we present the results for the regression of Wstexp on size, unemployment rate, per capita income, delinquency ratio and a dummy variable for credit unions (dummy=0) and Subchapter S banks (dummy=1). We present the results for each Individual year from 2005 to 2010. The following acronyms are used: Size (log (total assets)), Lpcir (log (per capita income)), Urr (unemployment rate), and Delequencyratio (delinquent loans/total loans). *, ** and *** denote, respectively 10\%, 5\% and 1\% levels of significance.

\begin{tabular}{|c|c|c|c|c|c|c|}
\hline \multicolumn{7}{|c|}{ Regression results for Wstexp } \\
\hline & 2005 & 2006 & 2007 & 2008 & 2009 & 2010 \\
\hline \multicolumn{7}{|c|}{ Independent Variables: } \\
\hline Constant & $1.0923 * * *$ & $0.9207 * * *$ & $0.8743 * * *$ & $0.9931 * * *$ & $0.7726^{* * *}$ & $0.6868 * * *$ \\
\hline Scode & 0.0073 & $-0.0131 * *$ & $-0.0093 *$ & 0.0015 & 0.0034 & 0.0112 \\
\hline Size & $-0.0082 * *$ & $-0.01 * * *$ & $-0.0128 * * *$ & $-0.0055^{*}$ & -0.0039 & -0.0012 \\
\hline Urr & -0.0029 & -0.003 & $-0.0058 * *$ & $-0.0101 * * *$ & -0.0027 & $-0.0042 * *$ \\
\hline Lpcir & $-0.0546 * * *$ & $-0.0373 * * *$ & $-0.0284 * * *$ & $-0.0487 * * *$ & -0.0315 & -0.0261 \\
\hline Delequencyratio & -0.0224 & 0.0012 & -0.0095 & $-0.0139 *$ & $-0.013 * *$ & $-0.012 * *$ \\
\hline \# of Obs & 520 & 593 & 660 & 597 & 373 & 303 \\
\hline R-Squared & 0.0541 & 0.0427 & 0.0589 & 0.0638 & 0.0227 & 0.0364 \\
\hline
\end{tabular}


Table 12: Comparison of credit unions and Subchapter S banks: Optexp

In this table we present the results for the regression of Optexp on size, unemployment rate, per capita income, delinquency ratio and a dummy variable for credit unions (dummy=0) and Subchapter S banks (dummy=1). We present the results for each Individual year from 2005 to 2010. The following acronyms are used: Size (log (total assets)), Lpcir (log (per capita income)), Urr (unemployment rate), and Delequencyratio (delinquent loans/total loans). *, ** and *** denote, respectively 10\%, 5\% and 1\% levels of significance.

\begin{tabular}{|c|c|c|c|c|c|c|}
\hline \multicolumn{7}{|c|}{ Regression results for Optexp } \\
\hline & 2005 & 2006 & 2007 & 2008 & 2009 & 2010 \\
\hline \multicolumn{7}{|c|}{ Independent Variables: } \\
\hline Constant & $0.4959 * * *$ & $0.4712 * * *$ & $0.4571 * * *$ & $0.4659 * * *$ & $0.3199 * *$ & $0.3246^{*}$ \\
\hline Scode & $-0.0795 * * *$ & $-0.0782 * * *$ & $-0.0734 * * *$ & $-0.0707 * * *$ & $-0.0665 * * *$ & $-0.0687 * * *$ \\
\hline Size & -0.0025 & $-0.0032 *$ & $-0.0044 * *$ & -0.0015 & 0.0013 & 0.0011 \\
\hline Urr & -0.0031 & -0.0013 & -0.0012 & $-0.0028 * *$ & 0.0005 & -0.0002 \\
\hline Lpcir & $-0.0251 * * *$ & $-0.0236^{* * *}$ & $-0.0208^{* *}$ & $-0.0256 * * *$ & -0.0184 & -0.0175 \\
\hline Delequencyratio & -0.0078 & 0.0032 & -0.003 & -0.0012 & -0.0055 & 0.0003 \\
\hline \# of Obs & 520 & 593 & 660 & 597 & 373 & 303 \\
\hline R-Squared & 0.4374 & 0.4687 & 0.4599 & 0.3999 & 0.3862 & 0.3926 \\
\hline
\end{tabular}


Table 13: Comparison of credit unions and Subchapter S banks: return on equity

In this table we present the results for the regression of return on equity on size, unemployment rate, per capita income, delinquency ratio and a dummy variable for credit unions (dummy=0) and Subchapter S banks (dummy=1). We present the results for each Individual year from 2005 to 2010. The following acronyms are used: Size (log (total assets)), Lpcir (log (per capita income)), Urr (unemployment rate), and Delequencyratio (delinquent loans/total loans). *, ** and *** denote, respectively $10 \%, 5 \%$ and $1 \%$ levels of significance.

\begin{tabular}{|c|c|c|c|c|c|c|}
\hline \multicolumn{7}{|c|}{ Regression results for Roe } \\
\hline & 2005 & 2006 & 2007 & 2008 & 2009 & 2010 \\
\hline \multicolumn{7}{|c|}{ Independent Variables: } \\
\hline Constant & -0.0363 & 0.1567 & $0.2653 * *$ & $0.421 * * *$ & $0.4386^{* *}$ & $0.4646^{* *}$ \\
\hline Scode & $0.1002 * * *$ & $0.0997 * * *$ & $0.0815^{* * *}$ & $0.0561 * * *$ & $0.0345 * * *$ & $0.0403 * * *$ \\
\hline Size & $0.0114 * * *$ & $0.0138 * * *$ & $0.0111 * * *$ & $0.0069 * * *$ & $0.0113 * * *$ & $0.0089 * * *$ \\
\hline Urr & -0.0009 & $-0.0072 * * *$ & $-0.0064 * *$ & $-0.0076^{* * *}$ & $-0.0029 *$ & $-0.0034 * *$ \\
\hline Lpcir & -0.0093 & $-0.0298 * * *$ & $-0.036 * * *$ & $-0.0425 * * *$ & $-0.0537 * * *$ & $-0.0518 * * *$ \\
\hline Delequencyratio & -0.0183 & -0.0065 & -0.0049 & $-0.0165 * *$ & -0.0081 & 0.0011 \\
\hline$\#$ of Obs & 520 & 593 & 660 & 597 & 373 & 303 \\
\hline R-Squared & 0.3982 & 0.4258 & 0.3427 & 0.2547 & 0.1357 & 0.1926 \\
\hline
\end{tabular}


Table 14: Comparison of credit unions and Subchapter S banks: return on assets

In this table we present the results for the regression of return on assets on size, unemployment rate, per capita income, delinquency ratio and a dummy variable for credit unions (dummy=0) and Subchapter S banks (dummy=1). We present the results for each individual year from 2005 to 2010. The following acronyms are used: Size (log (total assets)), Lpcir (log (per capita income)), Urr (unemployment rate), and Delequencyratio (delinquent loans/total loans). *, ** and *** denote, respectively $10 \%, 5 \%$ and $1 \%$ levels of significance.

\begin{tabular}{|c|c|c|c|c|c|c|}
\hline \multicolumn{7}{|c|}{ Regression results for Road } \\
\hline & 2005 & 2006 & 2007 & 2008 & 2009 & 2010 \\
\hline \multicolumn{7}{|c|}{ Independent Variables: } \\
\hline Constant & -0.0219 & -0.0013 & 0.0104 & $0.0363 * * *$ & $0.0421 *$ & $0.0382 *$ \\
\hline Scode & $0.0082 * * *$ & $0.0086^{* * *}$ & $0.0068 * * *$ & $0.0043 * * *$ & $0.0033 * * *$ & $0.0036 * * *$ \\
\hline Size & $0.0011 * * *$ & $0.0011 * * *$ & $0.0009 * * *$ & $0.0005 *$ & $0.0008 * *$ & 0.0005 \\
\hline Urr & 0.0001 & $-0.0005 * *$ & $-0.0006^{*}$ & $-0.0006^{* * *}$ & -0.0002 & -0.0002 \\
\hline Lpcir & 0.0009 & -0.0008 & -0.0016 & $-0.0033 * * *$ & $-0.0047 * *$ & $-0.0038 * *$ \\
\hline Delequencyratio & -0.0004 & -0.0009 & 0.0003 & -0.001 & -0.0008 & 0.0004 \\
\hline \# of Obs & 520 & 593 & 660 & 597 & 373 & 303 \\
\hline R-Squared & 0.2861 & 0.3027 & 0.2358 & 0.1662 & 0.0979 & 0.1313 \\
\hline
\end{tabular}


CHAPTER 4: ESSAY 3

\section{ASSET QUALITY COMPARISON BETWEEN CREDIT UNIONS AND SUBCHAPTER S BANKS}

\subsection{Introduction}

Performance of any banking institution depends on the quality of the assets. The financial crisis during 2008-2009 has been marked by an overwhelming decrease in banking industry profits and a large number of bank failures. The series of bank failure not only shatters the public confidence in the banking system but also depletes the resources of the insurance fund provided by the FDIC. According to Knaup and Wagner (2009) asset quality indicators help supervisors and regulators to monitor and identify weak banks and put them under increased scrutiny. In fact, the asset quality of financial institutions has gained increased scrutiny in the wake of recent financial crisis.

In essay 2 we have compared not for profit credit unions with for profit Subchapter S banks to investigate which of the two is doing a better job of sharing the tax benefit with its customers. We find that in comparison with credit unions, the Subchapter $\mathrm{S}$ banks are doing a superior job at sharing the tax benefit with their customers.

In this essay we further hypothesize that the difference in the ownership structure and objectives of the credit unions and the Subchapter S banks may influence the asset quality of these financial institutions and we specifically investigate which of the two has better asset quality in the post crisis period. However, a priori, we do not have any evidence or economic rationale to argue in favor of one or the other except that the credit unions could end up with poor asset quality as they serve the individuals of limited means whereas the Subchapter S banks could make risky loans to maximize the profits. Based 
on this argument alone, one can rationalize that credit unions will have relatively poor asset utilization.

The credit unions are member owned whereas the Subchapter S banks are privately owned by the shareholders of the bank. The federal credit unions are exempted from federal and state income taxes and do not pay taxes on their retained earnings as well. Small Business Job Protection Act of 1996 allows Subchapter S banks to avoid double taxation just like credit unions. However, the shareholders of the Subchapter S banks have to pay taxes on the retained earnings. The credit union industry has cooperative not for profit structure and has a special objective of serving individuals of limited means whereas; the objective of privately owned Subchapter S banks is to maximize shareholder's wealth while serving the community. The supporters of tax exemption to credit unions argue that credit unions have provided a valuable alternative to for profit banking system and serves people who have no or limited access to other financial services $^{14}$. The financial crisis of 2008-09 has affected the asset quality of financial institutions including credit unions and Subchapter S banks. Therefore, we use data for the year 2010 to compare the asset quality of credit unions and Subchapter S banks in the post financial crisis period.

In this essay we use three different measures of asset quality to compare credit unions with Subchapter S banks. These asset quality measures are; (1) allowance for loan losses as a percentage of total loans (All1); (2) net charge-offs as a percentage of average assets (Nco) and; (3) non-performing assets as a percentage of total assets (Npata). The

\footnotetext{
${ }^{14}$. U.S. Department of the Treasury "Comparing Credit Unions and Other Depository Institutions", January 2001. Page 28.)
} 
allowance for loan losses is an estimate of the amount of losses that are likely to result from all of the loans in the bank's portfolio. According to Walter (1991), FDIC (Federal Deposit Insurance Corporation) requires that all financial institutions including credit unions and Subchapter S banks report allowance for loan losses as a contra asset account on their balance sheets. The net charge-off is the difference between gross charge-off and any subsequent recoveries of delinquent loans that were previously classified as uncollectible. The bad debt is written off by the bank and is classified as gross chargeoffs. However, if there is a recovery on previously written off debt, it is subtracted from the gross charge-off to compute net charge-off. The non-performing assets include nonperforming loans and other assets that banks have taken possession typically through foreclosure.

As a robustness test we use net interest margin (Nim) as an indirect measure of asset quality and compare credit unions and Subchapter S banks. Financial institutions with risky assets are expected to generate higher revenues in the form of interest income which may lead to higher net interest margin. The net interest margin is defined as the difference between revenue and financial costs as a percentage of average earning assets and has a negative relationship with asset quality.

We also compare the asset utilization at credit unions and Subchapter S banks to investigate which of the two is putting its assets to better use. We measure the asset utilization by comparing the total loans made as a percentage of total assets. We find that the Subchapter S banks have higher allowance for loans and lease losses (Alll) but there is no significant difference in net charge-off (Nco) at the two institutions. We find that Subchapter S banks have higher non-performing assets (Npata). We find that the asset 
utilization measured by total loans as a percentage of total assets (Tlta) is higher at Subchapter S banks and net interest margin (Nim) is also higher at Subchapter S banks. Overall, we find that Subchapter S banks have poorer asset quality but they are doing a better job at utilizing assets and generating higher revenues.

The remainder of the paper is organized as follows. In section 2, we provide the relevant literature and discuss the research questions. In section 3, we present the details about the sample construction and variables of interest. In section 4, we present the methodology. In section 5, we present the results. In section 6, we present the conclusion.

\subsection{Literature Review}

There is an extensive work done on the asset quality of financial institutions and researchers have also investigated the determinants of this asset quality. Clair (1992) analyzes the relationship between loan quality and loan growth at Texas banks using the data from 1976 to 1990 . He estimated the loan quality using non-performing loan ratios and charge-off rates. He finds a negative influence of loan growth on non-performing loans and the loan charge-off rate for the first year after a bank's credit expansion, whereas relationship was weaker for Subsequent years. He suggests that the relationship between loan growth and loan quality deterioration appears to depend on a bank's equity position.

Research in the past has also focused on the information advantage hypothesis (IAH). The IAH posits that the small community banks have an information advantage in evaluating and monitoring loan quality. Nakamura (1994) finds that the small banks have a better organizational structure that gives them an edge in processing information over large banks with respect to loans offered to small businesses. This is attributed to a closer 
relationship between the small businesses and the loan officers. Moreover, the loan officers at small banks have better access to confidential information about the financial activities of the borrowing firm which helps in better monitoring of the loans and better asset quality.

Angbanzo (1997) used the Bank Call Report data from 1989 to 1993 to investigate if the banks with riskier loans and higher interest-rate risk exposure strive to achieve higher net interest margins. He finds that the interest margins reflect default and interest rate risk premium.

Akhigbe, McNulty and Verbrugge (2001) investigate the loan quality at small banks in the deregulated environment. They investigate and compare the loan quality at small banks from 1986 to 1996 for all Florida banks. They define a bank as small if the assets of the bank are under $\$ 500$ million. They compare four different loan quality measures and did not find systematic evidence that loan quality is better at small banks. Specifically, they find that net charge-offs and loan loss provisions are lower at small banks located in non-metropolitan areas. However they find that non-performing loans and other real estate owned are higher at small banks.

Frame, Karels and McClatchey (2001) evaluate the effect of the common bond and membership expansion on credit union risk using data from the 1997 Call and Income Reports. They classify federal credit unions on the basis of common bond of occupation, association, or geographic area. It is interesting to note that the membership at credit unions is based on affinity among members or a common bond. The membership at occupational credit unions is limited to individuals sharing a common employer, the members of associational credit unions include members of a religious group or a civic 
group and the membership at residential or community credit unions is limited to individuals of a particular residential area or community. They find that asset quality at occupational credit unions is better perhaps because their members are employed and they have informational advantages and better monitoring mechanism. They compared asset quality within the credit unions whereas our study extends the asset quality comparison of credit unions with Subchapter S banks.

Laeven and Majnoni (2003) analyzed bank loan loss provisioning at large commercial banks from 45 countries during the period 1988-1999. They find that there is a delay at many banks when it comes to provisioning for bad loans which might magnify the impact of the economic cycle on banks' income and capital. They also find that bank's provision for loan losses are too little in good times of the economic cycle and banks overreact in bad times.

Researchers in the past have focused on different aspects of asset quality. They have investigated the impact of factors like size, loan growth, economic cycle, informational advantage, etc. on asset quality of financial institutions and all of the studies cited above have used the pre financial crisis data. The financial crisis of 2008-09 has severely affected the asset quality at financial institutions as a result of subprime mortgages and other bad loans. In this study, we use the data from post financial crisis period to compare the asset quality of credit unions and Subchapter S banks which have similar tax exemptions but different objectives and ownership structure. 


\subsection{Data}

Our sample consists of federally chartered credit unions and Subchapter S banks for the year 2010. We collect the data on Subchapter S banks from Highline Financial database and the data for credit unions from the website of National Credit Union Administration (NCUA). Highline financials is the comprehensive database, which provides detail financial information for financial institutions including commercial banks and bank holding companies. A number of credit unions are small without a comparable Subchapter S bank and some credit unions are bigger than a comparable Subchapter S bank, so we delete institutions below $\$ 50$ million and above $\$ 3$ billion from the sample.

We collect all the relevant data from the following sources;

1. per capita income by county from the website of the US Department of Commerce, Bureau of Economic Analysis

2. unemployment rate from the website of US Department of Labor, Bureau of Labor Statistics.

The following is the description of variables used in this study:

- $\quad$ Size $=\log$ of total assets

- $\quad$ Alll = allowance for loan losses as a percentage of total loans

- $\mathrm{Nco}=$ net charge-offs as a percentage of average assets

- $\quad$ Npata $=$ non-performing assets as a percentage of total assets

- $\quad$ Tlta $=$ total loans as a percentage of total assets

- $\quad$ Nim $=$ net interest margin

- $\quad \mathrm{Urr}=$ the unemployment rate of county in which bank is located

- $\quad$ Lpcir $=$ the log of per capita income of the county in which bank is located 
- $\quad$ Scode (dummy variable $)=1$ if bank is Subchapter S, 0 otherwise

\subsection{Methodology}

We use the annual data for the Subchapter S banks and credit unions for the year 2010 for our empirical analysis. We perform both univariate analysis as well as multivariate regressions.

Univariate Analysis:

Our goal is to test if the relevant attributes for the credit unions $\left(\mu_{1}\right)$ are different from the corresponding attributes of the Subchapter S banks $\left(\mu_{2}\right)$. Hence we test the following null-hypothesis:

$$
H_{0}: \mu_{1}-\mu_{2}=0
$$

Against the alternative hypothesis:

$$
H_{1}: \mu_{1}-\mu_{2} \neq 0
$$

We first determine whether the population variances are statistically equal using the Snedecor's F-test. If we find that the population variances are statistically same then we use the standard two-independent sample t-test to test the null hypothesis posited above. ${ }^{15}$ If, we find that the population variances are statistically unequal, we use the two independent sample t-test for equality of population means proposed by Satterthwaite

\footnotetext{
${ }^{15}$ For the test statistics and procedures to test the equality of two population variances and the equality of two population means when population variances are unknown but equal see any basic standard statistics textbook.
} 
(1946). If the null hypothesis is true, the t-statistic will have Student's t-distribution with Welch's (1947) “modified” degrees of freedom given by,

$$
d f=\frac{\left(\frac{s_{1}^{2}}{n_{1}}+\frac{s_{2}^{2}}{n_{2}}\right)^{2}}{\frac{\left(s_{1}^{2} / n_{1}\right)^{2}}{n_{1}}+\frac{\left(s_{2}^{2} / n_{2}\right)^{2}}{n_{2}}}
$$

Where $n_{i}$ and $s_{i}^{2}(i=1,2)$ respectively are the sample size and the sample variance of the $i^{\text {th }}$ sample.

Multivariate Analysis:

Following Mayne (1977) and Thomson (1991), in our multivariate analysis, we use county unemployment rate and the per-capita income to control for local economic factors. Furthermore, we control for the size of credit unions and the Subchapter S banks because economies of scale are experienced by banks and credit unions as they grow larger. Moreover large credit unions and Subchapter S banks are likely to be raise funds in the money markets, and markets respond favorably to lower non-performing loans which motivates banks to charge-off bad loans rather than carry them as non-performing assets. Therefore, large financial institutions have an incentive to charge-off troubled loans to gain more favorable access to money markets.

In equations (4.1) to (4.5) we regress a particular dependent variable on over a dummy variable Scode which takes a value of 0 for credit unions and a value of 1 for Subchapter S banks as well as other independent variables e.g., Size, Urr, and Lpcir. Our variable of interest is the sign and statistical significance of the dummy variable Scode in 
each case whereas the other variables are the control variables. We use three different measures of loan quality as the dependent variables to compare the asset quality of the credit unions with Subchapter S banks. So we have three different models to compare the asset quality (equation 4.1 to equation 4.3) of credit unions and Subchapter S banks. For example, in equation (4.1) we investigate the significance of the dummy variable Scode. A positive and significant coefficient on Scode would indicate that the Alll for the Subchapter S bank is higher. Similarly in (equation 4.2), a positive and significant coefficient on Scode would indicate that the Nco for the Subchapter S bank is higher and in (equation 4.3), a positive and significant coefficient on Scode would indicate that the Npata for the Subchapter S bank is higher.

$$
\begin{aligned}
& \text { Alll }=\alpha+\beta_{1} \text { Scode }+\beta_{2} \text { Size }+\beta_{3} \text { Urr }+\beta_{4} \text { Lpcir }+\mathcal{E} \\
& N c o=\alpha+\beta_{1} \text { Scode }+\beta_{2} \text { Size }+\beta_{3} \text { Urr }+\beta_{4} \text { Lpcir }+\varepsilon \\
& \text { Npata }=\alpha+\beta_{1} \text { Scode }+\beta_{2} \text { Size }+\beta_{3} \text { Urr }+\beta_{4} \text { Lpcir }+\mathcal{E}
\end{aligned}
$$

We use equation (4.4) to analyze whether credit unions or Subchapter S banks are doing a better job of putting assets to good use. A positive and significant coefficient on Scode would indicate that the asset utilization for the credit unions is lower.

Tlta $=\alpha+\beta_{1}$ Scode $+\beta_{2}$ Size $+\beta_{3} U r r+\beta_{4} L p c i r+\varepsilon$

We use equation (4.5) to compare the profitability of borrowing and lending activities at credit unions and Subchapter S banks. A positive and significant coefficient on Scode would indicate lower interest margin for the credit unions.

Nim $=\alpha+\beta_{1}$ Scode $+\beta_{2}$ Size $+\beta_{3} U r r+\beta_{4}$ Lpcir $+\varepsilon$ 


\subsection{Results and Analysis}

In Table 15, we present the univariate analysis of the variables of interest for the credit unions and Subchapter S banks. We find that the allowance for loan loss as a percentage of total loans (All1) is higher for Subchapter S banks. We find that net chargeoff as a percentage of average assets (Nco) are higher for credit unions. The nonperforming assets as a percentage of total assets (Npata) are also significantly higher for Subchapter S banks. The univariate results hints at better asset utilization by Subchapter $\mathrm{S}$ banks as the total loans and leases as a percentage of total assets (Tlta) is significantly higher for Subchapter S banks. The profitability of the borrowing and lending activities is higher at Subchapter S banks as the net interest margin (Nim) is significantly higher for Subchapter S banks as compared to credit unions.

In Table 16, we present the results of the regression analysis on Alll (Allowance for loan losses as a percentage of total loans). We find the coefficient on Scode to be positive and significant in Alll regression (equation 4.1), indicating that Subchapter S banks have higher allowance for loan losses as compared to credit unions. The positive and a significant coefficient on Size show that allowance for loan losses increases as the size of the bank/credit union increases.

In Table 17, we present the results of the regression analysis on Nco (Net chargeoffs as a percentage of average assets). We find the coefficient on Scode is not significant for the Nco regression (equation4.2), indicating that there is no significant difference in net charge-off for the Subchapter S banks and credit unions.

In Table 18, we present the results of the regression analysis on Npata (Nonperforming assets as a percentage of total assets). We find the coefficient on Scode to be 
positive and significant for the regression (equation 4.3), indicating that Subchapter S banks have higher non-performing assets as compared to credit unions.

In Table 19, we present the results of the regression analysis on Tlta (Total loans and leases as a percentage of total assets). The coefficient on Scode is positive and significant for Tlta regression (equation 4.4) which indicates that Subchapter S banks have better asset utilization as compared to credit unions.

Finally, in Table 20, we present the results of the regression analysis on Nim (Net interest Margin). We regress Nim on the Scode dummy and the set of control variables (equation 4.5). We find that the coefficient on Scode is positive and highly significant. The regression results indicate that the net interest margin for the credit unions is significantly less than that for Subchapter S banks.

Our results indicate that Subchapter S banks have higher allowance for loan losses as a percentage of total loans (All1). However, we find no significant difference between the net charge-off (Nco). We find that Subchapter S banks have higher non-performing assets as a percentage of total assets (Npata). We also find that Subchapter S banks have better asset utilization indicated by total loans as a percentage of total assets (Tlta) and also have higher net interest margin (Nim) as compared to credit unions.

\subsection{Conclusion}

In this essay, we compare the asset quality of not for profit credit unions with for profit Subchapter S banks to investigate which of the two has better asset quality in the post crisis period. We use allowance for loan losses as a percentage of total loans (Alll), net charge-off as a percentage of average assets (Nco) and non-performing assets as a percentage of total assets (Npata) to compare the asset quality of credit unions and 
Subchapter S banks. We find that the Subchapter S banks have higher allowances for loan losses to avoid financial distress but net charge-off is not significantly different from credit unions. The non-performing assets are higher at Subchapter S banks indicating that overall loan quality may be poor at Subchapter S banks. Subchapter S banks have better asset utilization as indicated by total loans as a percentage of total assets (Tlta) and also have higher net interest margin (Nim). Overall, we find that credit unions have a better asset quality but Subchapter S banks are superior in utilizing assets and generating higher net interest margin. 
Table 15: Asset quality of credit unions and Subchapter S banks: univariate analysis

The table shows the mean and standard deviation of selected variables for the year 2010 for the complete sample of credit unions and Subchapter S banks. The results of t-tests on the differences in the means of the variables of interest are presented; *,** and *** denote significant differences between the samples means at respectively $10 \%, 5 \%$ and $1 \%$ levels of significance.

\begin{tabular}{|c|c|c|c|c|c|c|}
\hline \multirow[b]{2}{*}{ Variable } & \multicolumn{2}{|c|}{ Credit unions } & \multicolumn{2}{|c|}{$\begin{array}{c}\text { Subchapter S } \\
\text { banks }\end{array}$} & \multirow[b]{2}{*}{ Diff } & \multirow[b]{2}{*}{$\begin{array}{l}\mathrm{p}- \\
\text { value }\end{array}$} \\
\hline & Mean & Std Dev & Mean & Std Dev & & \\
\hline Tlta & 58.1483 & 15.1785 & 63.1209 & 14.2202 & $-4.9726^{* * *}$ & 0.0001 \\
\hline Npata & 1.0748 & 1.1321 & 3.0207 & 3.8434 & $-1.9459 * * *$ & 0.0001 \\
\hline Alll & 1.2835 & 1.1328 & 1.7435 & 0.9277 & $-0.46 * * *$ & 0.0001 \\
\hline Nco & 0.8960 & 0.8511 & 0.7896 & 0.9959 & $0.1064 * * *$ & 0.0019 \\
\hline $\mathrm{Nim}$ & 3.5998 & 0.8332 & 4.1235 & 0.8174 & $-0.5238 * * *$ & 0.0001 \\
\hline Number of banks & 1177 & & 1800 & & & \\
\hline
\end{tabular}

Description of variables:

Tlta $=$ total loans as a percentage of total assets

Npata $=$ non-performing assets as a percentage of total assets

Alll $=$ allowance for loan losses as a percentage of total loans

$\mathrm{Nco}=$ net charge-offs as a percentage of average assets

$\mathrm{Nim}=$ net interest margin 
Table 16: Comparison of credit unions and Subchapter S banks: Alll regression

This table presents the regression coefficients on selected variables as well as their significance on the sample of credit unions and Subchapter S banks. The independent variables are used to control for firm size, unemployment rate and per capita income. The variable of interest is the Scode dummy, which takes value of 1 for Subchapter S banks, and of 0 for credit unions. *, ** and $* * *$ denote, respectively $10 \%, 5 \%$ and $1 \%$ levels of significance.

\begin{tabular}{lcrrr}
\hline Variable & Estimate & \multicolumn{2}{l}{$\begin{array}{l}\text { Std } \\
\text { Error }\end{array}$} & t-value \\
\hline & & & & VIF \\
Constant*** & -9.6148 & 1.0333 & -9.3051 & 0.0000 \\
Scode*** & 0.6650 & 0.0404 & 16.4514 & 1.2004 \\
Size*** & 0.1090 & 0.0217 & 5.0211 & 1.0169 \\
Urr*** & 0.0936 & 0.0077 & 12.2256 & 1.1925 \\
Lpcir*** & 0.7522 & 0.0921 & 8.1688 & 1.2823 \\
& & & & \\
\hline Number of observations & & 2942 & & \\
R-Squared & 0.1113 & & & \\
\hline
\end{tabular}

Description of variables:

Alll $=$ allowance for loan losses as a percentage of total loans

Scode $=$ dummy variable (a value of 0 for credit unions and 1 for Subchapter S banks)

Size $=\log$ of total assets

Urr $=$ unemployment rate

Lpcir $=\log$ of per capita income 
Table 17: Comparison of credit unions and Subchapter S banks: Nco regression

This table presents the regression coefficients on selected variables as well as their significance on the sample of credit unions and Subchapter S banks. The independent variables are used to control for firm size, unemployment rate and per capita income. The variable of interest is the Scode dummy, which takes value of 1 for Subchapter S banks, and of 0 for credit unions. *, ** and $* * *$ denote, respectively $10 \%, 5 \%$ and $1 \%$ levels of significance.

\begin{tabular}{lcrrr}
\hline Variable & Estimate & Std Error & t-value & VIF \\
\hline & & & & \\
Constant*** & -7.9605 & 0.9639 & -8.2590 & 0.0000 \\
Scode & 0.0611 & 0.0377 & 1.6189 & 1.2000 \\
Size*** & 0.1047 & 0.0203 & 5.1692 & 1.0170 \\
Urr*** & 0.0811 & 0.0071 & 11.3519 & 1.1923 \\
Lpcir*** & 0.5780 & 0.0859 & 6.7290 & 1.2819 \\
& & & & \\
\hline Number of observations & & 2943 & & \\
R-Squared & 0.0581 & & \\
\hline
\end{tabular}

Description of variables:

$\mathrm{Nco}=$ net charge-off as a percentage of total loans

Scode $=$ dummy variable (a value of 0 for credit unions and 1 for Subchapter S banks)

Size $=\log$ of total assets

Urr $=$ unemployment rate

Lpcir $=\log$ of per capita income 
Table 18: Comparison of credit unions and Subchapter S banks: Npata regression This table presents the regression coefficients on selected variables as well as their significance on the sample of credit unions and Subchapter S banks. The independent variables are used to control for firm size, unemployment rate and per capita income. The variable of interest is the Scode dummy, which takes value of 1 for Subchapter S banks, and of 0 for credit unions. *, ** and *** denote, respectively $10 \%, 5 \%$ and $1 \%$ levels of significance.

\begin{tabular}{lrrrr}
\hline Variable & Estimate & Std Error & t-value & VIF \\
\hline & & & & \\
Constant*** & -23.8801 & 3.1931 & -7.4787 & 0.0000 \\
Scode*** & 2.4134 & 0.1249 & 19.3176 & 1.2000 \\
Size*** & 0.2831 & 0.0671 & 4.2179 & 1.0170 \\
Urr*** & 0.2524 & 0.0237 & 10.6647 & 1.1923 \\
Lpcir*** & 1.6317 & 0.2846 & 5.7340 & 1.2819 \\
& & & & \\
\hline Number of observations & & 2943 & & \\
R-Squared & 0.1291 & & \\
\hline
\end{tabular}

\section{Description of variables:}

Npata $=$ non-performing Asset as percentage of total assets

Scode $=$ dummy variable (a value of 0 for credit unions and 1 for Subchapter S banks)

Size $=\log$ of total assets

Urr $=$ unemployment rate

Lpcir $=\log$ of per capita income 
Table 19: Comparison of credit unions and Subchapter S banks: Tlta regression

This table presents the regression coefficients on selected variables as well as their significance on the sample of credit unions and Subchapter S banks. The independent variables are used to control for firm size, unemployment rate and per capita income. The variable of interest is the Scode dummy, which takes value of 1 for Subchapter S banks, and of 0 for credit unions. * $* *$ and $* * *$ denote, respectively $10 \%, 5 \%$ and $1 \%$ levels of significance.

\begin{tabular}{lrrrr}
\hline Variable & Estimate & Std Error & t-value & VIF \\
\hline & & & & \\
Constant*** & 47.6369 & 15.3053 & 3.1124 & 0.0000 \\
Scode*** & 4.5549 & 0.5988 & 7.6062 & 1.2000 \\
Size*** & 2.1436 & 0.3217 & 6.6636 & 1.0170 \\
Urr & -0.0688 & 0.1134 & -0.6066 & 1.1923 \\
Lpcir** & -2.7721 & 1.3640 & -2.0324 & 1.2819 \\
& & & & \\
\hline Number of observations & & 2943 & & \\
R-Squared & 0.0421 & & & \\
\hline
\end{tabular}

Description of variables:

Tlta $=$ total loans as a percentage of total assets

Scode $=$ dummy variable (a value of 0 for credit unions and 1 for Subchapter S banks)

Size $=\log$ of total assets

Urr $=$ unemployment rate

Lpcir $=\log$ of per capita income 
Table 20: Comparison of credit unions and Subchapter S banks: Nim regression

This table presents the regression coefficients on selected variables as well as their significance on the sample of credit unions and Subchapter S banks. The independent variables are used to control for firm size, unemployment rate and per capita income. The variable of interest is the Scode dummy, which takes value of 1 for Subchapter S banks, and of 0 for Credit Unions. *, ** and *** denote, respectively $10 \%, 5 \%$ and $1 \%$ levels of significance.

\begin{tabular}{lrrrr}
\hline Variable & Estimate & Std Error & t-value & VIF \\
\hline & & & & \\
Constant*** & 12.1653 & 0.8572 & 14.1913 & 0.0000 \\
Scode*** & 0.4171 & 0.0335 & 12.4371 & 1.2000 \\
Size*** & -0.0960 & 0.0180 & -5.3279 & 1.0170 \\
Urr*** & -0.0234 & 0.0064 & -3.6805 & 1.1923 \\
Lpcir*** & -0.6177 & 0.0764 & -8.0851 & 1.2819 \\
& & & & \\
\hline Number of observations & 2943 & & & \\
R-Squared & 0.1195 & & & \\
\hline
\end{tabular}

Description of variables:

$\mathrm{Nim}=$ net Interest Margin

Scode $=$ dummy variable (a value of 0 for credit unions and 1 for Subchapter S banks)

Size $=\log$ of total assets

Urr $=$ unemployment rate

Lpcir $=\log$ of per capita income 


\section{CHAPTER 5: CONCLUSION}

The credit unions and Subchapter $\mathrm{S}$ banks are both exempted from federal taxation at corporate level and these tax exemptions have resulted in the loss of revenues to the government and therefore it becomes economically important to investigate the effect of tax exemptions. The dissertation investigates the effect of tax exemption on competitiveness, performance and portfolio risk of credit unions and Subchapter S banks.

The first essay of this dissertation investigates the effect of bank's adoption of the Subchapter S status on its stakeholders. We find that the customers of the Subchapter S banks which comprises of the depositors and the borrowers do not receive the benefits of tax exemption in the form of higher deposit rates or lower loan rates. The employees of the bank are not benefitted as they do not receive higher salaries and benefits after the adoption of Subchapter S status. The sole beneficiaries of the tax benefit are the owners or the shareholders of the bank as return on equity is significantly higher after the adoption of Subchapter S status. Interestingly enough, the tax exemptions to Subchapter S banks do not lead to higher employment opportunities at banks that adopt Subchapter S status. The findings will have significant policy implications about the ongoing debate if tax exemptions to businesses create jobs.

The second essay extends the analysis to credit unions which receive a larger tax benefit as they do not pay taxes on retained earnings. In this essay we compare member owned not for profit credit unions with privately owned for profit Subchapter S banks to investigate which of the two is doing a better job of sharing the tax benefit with its customers. The analyses are conducted for the combined period from 2005- 2010 and 
also for each of the individual years separately. We find that the credit unions are not doing a better job at sharing tax benefit with its customers. The results indicate that credit unions do not offer lower loan rates to borrowers or higher deposit rates to depositors as compared to Subchapter S banks. Moreover the credit union customers pay a higher service fee as compared to the customers of Subchapter S banks. We find that the operating expenses are higher for credit unions. We also find that the return on equity and the return on assets are significantly higher for Subchapter S banks as compared to credit unions indicating inefficient operations. Overall we find that in comparison with credit unions, the Subchapter S banks are doing a better job of sharing the tax benefit with its customers.

The third essay compares the asset quality of not for profit credit unions with for profit Subchapter S banks in the post crisis period. The tax exemptions may affect the asset quality of both credit unions and Subchapter S banks as credit unions are not for profit organizations and the objective is to serve the individuals of limited means, on the other hand Subchapter S banks are privately owned and may make decisions including making risky loans to maximize the shareholders wealth. We find that the Subchapter S banks have higher allowances for loan losses to avoid financial distress but net charge-off is not significantly different from credit unions. The non-performing assets are higher at Subchapter S banks indicating that overall loan quality may be poor at Subchapter S banks. Subchapter S banks have better asset utilization as indicated by total loans as a percentage of total assets and also have higher net interest margin. Overall, we find that 
credit unions have a better asset quality but Subchapter S banks are superior in utilizing assets and generating higher net interest margin.

The empirical findings of this dissertation have important policy implications. The results indicate that tax exemptions have resulted in "fattening the wallets" of the owners of the Subchapter S banks and inefficient operations at credit unions without any societal benefits as a whole, and these tax exemptions contribute to the so called one of the many tax loop-holes.

The findings of the dissertation have significant policy implications about the ongoing debate if tax exemptions to Subchapter S banks and credit unions are justified or create any value particularly in times of record budget deficits. The findings are also expected to extend the current knowledge on the effect of tax exemptions on the stakeholders, job creation, performance and portfolio risk of Subchapter S banks and credit unions. 


\section{REFERENCES}

Akhigbe, A., McNulty, J., and Verbugge, J. (2001). Small Bank Loan Quality in a Deregulated Environment: The Information Advantage Hypothesis. Journal of Economics and Business, 53, 325-339.

American Bankers Association. (2009). Subchapter S Banks vs. Credit Unions: An Unfair CU Tax Advantage. Position paper on http://www.aba.com.

Anderson, P. M. and Meyer, B. D. (2000). The Effects of the Unemployment Insurance Payroll Tax on Wages, Employment, Claims, and Denials. Journal of Public Economics $78: 1,81-106$.

Angbanzo, L. (1997). Commercial bank net interest margins, default risk, interest-rate risk and off-balance sheet banking. Journal of Banking and Finance, 21, 55-87.

Ashenfelter, O. and Card, D. (1985). Using the longitudinal structure of earnings to estimate the effect of training programs. Review of Economics and Statistics 67, 648660 .

Clair, R. (1992). Loan growth and loan quality: Some preliminary evidence from Texas banks. Federal Reserve Bank of Dallas, Economic Review 3rd quarter, 9-22.

Cyree, Ken B., Scott E. Hein, and Timothy W. Koch(2005). “Avoiding Double Taxation: The Case of Commercial Banks." Working Paper.

Depken II, Craig A., Hollans, H. and Swidler, S. (2010). Do tax benefits conferred to Sub-S banks affect their deposit or loan rates? Finance Research Letters, 7(4), 238-245.

Frame, W. S., Karels, G.V., McClatchey, C. (2001). The Effect of the Common Bond and Membership Expansion on Credit Union Risk. Federal Reserve Bank of Atlanta, Working Paper No. 2001-2010.

Frame, W.S., Karels, G.V., McClatchey, C. (2003). Do credit unions use their tax advantage to benefit members? Evidence from a cost function. Review of Financial Economics, 12, 23-48.

Gruber, J. and Poterba, J. (1994). Tax Incentives and the Decision to Purchase Health Insurance: Evidence from the Self-Employed. Quarterly Journal of Economics, 109, 701734.

Hinson, Y. , and Juras, P. E. (2002). Performance Evaluation of Credit Unions: Reaping the Benefit of Tax Exempt Status. Journal of Managerial Issues, 2, 145-161 
Hodder, L., McAnally, M.L. and Weaver, C.D. (2003). The Influence of Tax and Nontax Factors on Banks' Choice of Organizational Form. The Accounting Review, 78-1, 297325.

Hughes, J. P., Mester, L. J. and Moon, C. G. (2001). Are scale economies in banking elusive or illusive? evidence obtained by incorporating capital structure and risk-taking into models of bank production. Journal of Banking and Finance 25, 2169-2208.

Knaup, M. and Wagner, W. (2009). A Market-based Measure of Credit Quality and Banks' Performance During the Subprime Crisis. Tilburg University EBC Discussion Paper 06, 1-32.

Laeven, L., Majnoni, G. (2003). Loan loss provisioning and economic slowdowns: Too much, too late. Journal of Financial Intermediation, 12, 178-197.

Mayne, L.S. (1977). A comparative study of bank holding company affiliates and independent banks, 1969-1972. Journal of Finance, 32, 147-158.

Nakamura, L. (1994). Small Borrowers and the Survival of the Small Bank. Federal Reserve Bank of Philadelphia, Business Review, 3-15.

Rose, P. S. (1994). Nonbank Thrift Institutions: Credit Unions, Savings and Loan Associations, Savings Banks and Money Market Mutual Funds. In Money and Capital Markets: The Financial System in an Increasingly Global Economy, 5th Ed. Burr Ridge, IL: Richard D. Irwin, Inc. p. 123-146.

Satterthwaite, F. E. (1946). An approximate distribution of estimates of variance components. Biometrics Bulletin 2, 110-114.

Thomson, J.B. (1991). Predicting bank failures in the 1980s. Federal Reserve Bank of Cleveland: Economic Review First Quarter, 9-20.

Walter, J.R. (1991). Loan loss reserves. Federal Reserve Bank of Richmond, Economic Review, 77, 20-30.

Welch, B. L. (1947). The generalization of "Student's" problem when several different population variances are involved. Biometrika, 34, 28-35. 
VITA

\section{AJEET JAIN}

October 03, 1975

Born, Meerut, India

1996

B. Sc. (Hons.) Chemistry University of Delhi

Delhi, India

$1997-2005$

GlaxoSmithKline (India)

Delhi, India

2008

Master of Business Administration Alabama A and M University

Normal, Alabama

2012

Doctoral Candidate

Florida International University

Miami, Florida

\section{PUBLICATIONS AND PRESENTATIONS}

"The tax exemption to Subchapter S banks: who gets the benefit?" with Edward Lawrence and Arun J. Prakash. Southern Finance Association Meeting, Key West, FL, 2011 